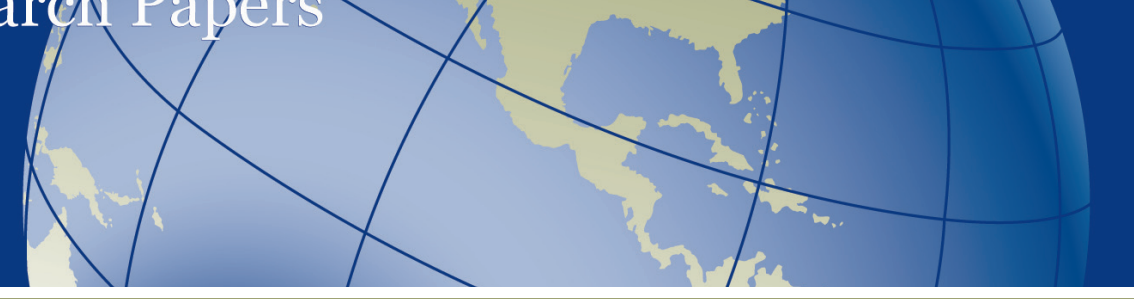

Volume 7 • Issue 22 - September 2014

\title{
REFORMING EQUALIZATION: BALANCING EFFICIENCY, ENTITLEMENT AND OWNERSHIP ${ }^{\dagger}$
}

\author{
Bev Dahlby
}

Distinguished Fellow, The School of Public Policy and

Professor, Department of Economics, University of Calgary

\section{SUMMARY}

In this paper, we provide an overview of the equalization grant system in Canada and the issues that have been raised concerning the reform of the fiscal transfer system. Any reforms to the equalization grant system have to balance three concerns - "efficiency" effects that arise through federal financing of transfers, and the incentive effects on provincial fiscal policies, "entitlement" to reasonably comparable public services at reasonably comparable levels of taxation, and "ownership" of resources and independence of fiscal policies by provincial governments. Five proposals for reform of the equalization system are discussed. With regard to the inclusion rate for resource revenues in equalization formula, we argue that the rate should be reduced from 50 per cent to 25 per cent and that ceiling on total equalization payments should be eliminated. We argue against the proposal to exempt from the calculation of equalization entitlements that are deposited in provincial sovereign wealth funds because this would not reduce total equalization entitlements in present value terms, it would be complex to implement if it extended to all forms of savings by provinces (such as debt reduction), and it would not alter the resource rich provinces' incentives to save more of their resource revenues. We argue against a proposal to reduce CHT and CST to provinces with above average fiscal capacities because this would reduce their incentive to develop and tax their resources, and it would be counter to the purpose of these block grants, which is to reduce the vertical fiscal imbalance between the federal and the provincial governments. We review the Gusen (2012a) proto-type model for incorporating variations in costs and needs in the computation of the equalization entitlements and argue that this procedure seems feasible and merits further analysis.

I would like to thank Mel McMillan, David Sewell, and an anonymous referee for their comments on a draft of this paper. They are not responsible for any of the errors, omissions or opinions expressed in this paper. 


\section{INTRODUCTION}

First recommended by the Rowell-Sirois Commission in 1940, federal equalization payments to reduce the differences in revenue-generating capacity among the provinces were introduced by the Liberal government of Louis St. Laurent in 1957. Ottawa's commitment to providing equalization was later incorporated into the Constitution as part of the patriation process initiated by Pierre Trudeau. The wording used to enshrine this commitment, however, is ambiguous, providing little guidance in designing or evaluating a specific equalization program. According to Section 36(2) of the Constitution Act, 1982:

Parliament and the Government of Canada are committed to the principle of making equalization payments to ensure that provincial governments have sufficient revenues to provide reasonably comparable levels of public services at reasonably comparable levels of taxation.

What are reasonably comparable "levels" of taxation? How are the "levels" of taxation to be interpreted? How much variation in public services is consistent with "reasonably comparable levels" of services - 10 per cent, 20 per cent or 50 per cent variations? What services should be compared across provinces - services to individuals, services to business or both? Should variations in the cost of providing public services across provinces affect equalization entitlements? Should provincial capital expenditures be treated differently than provincial expenditures on current services? All of these issues concerning permissible variations in the standard of service, the applicable range of public services and the measurement of services are complex and open to a range of interpretations.

The constitutional obligation to provide equalization grants is deliberately vague because the issues regarding the appropriate level of equalization are complex and do not admit to simple solutions. Furthermore, the objective of equalization may conflict with other objectives or constraints in the Constitution. Any reforms to the equalization grant system would have to balance concerns about:

- "efficiency" effects that arise through federal financing of transfers, the incentive effects on provincial fiscal policies and regulations and the consequent re-allocation of labour and capital within the economy;

- "entitlement" to reasonably comparable public services at reasonably comparable levels of taxation; and

- "ownership" of resources and independence of fiscal policies by provincial governments.

Achieving a fine balance of these goals is not easy. Inevitably, there will be differences in the emphasis that commentators and government officials place on each. A frank and open discussion of the objectives, constraints and trade-offs is necessary to understand the competing points of view on how the equalization system should be structured or reformed.

This paper provides an overview of the equalization grant system in Canada as well as the issues that have been raised concerning its reform. In the next section of this paper, we summarize some of the main points from the theoretical frameworks that have been developed to evaluate equalization transfers. In the following section of this paper, we provide a statistical overview of the current equalization program, including measures of fiscal capacity and disparities in 
provincial tax rates and expenditures. A subsequent section of this paper is devoted to examining the prominent reform proposals put forward over the years by commentators and provincial governments. The paper concludes with a list of recommendations on how the equalization system can best be reformed.

\section{FRAMEWORKS FOR EVALUATING EQUALIZATION TRANSFERS}

It is important to have analytical frameworks or models that provide a rationale for equalization grants when evaluating the system. The economics literature on intergovernmental grants is vast and here we will only present a brief summary of the aspects that are most relevant to the reform of the Canadian fiscal transfer system. ${ }^{l}$ For our purposes, we will parse the theoretical literature into models of (a) labour mobility and net fiscal benefits, (b) horizontal and vertical fiscal imbalances in the marginal cost of public funds and (c) regional shocks and fiscal insurance. In the final part of this section, we will examine a model used by Dahlby to evaluate the trade-off between efficiency and fiscal equity. ${ }^{2}$

\section{Labour Mobility and Net Fiscal Benefits}

In their seminal article, "Efficiency And Equalization Payments In A Federal System Of Government: A Synthesis And Extension Of Recent Results," Boadway and Flatters provide the rationale for equalization transfers in a federation based on the inefficient regional allocation of labour that can arise from a household's decision of where to live and work. Only the key aspects of this framework, which has been extended over the years by Boadway and his co-authors and extensively reviewed elsewhere by Boadway and Tremblay, will be outlined here. ${ }^{3}$ The basic assumption of the model is that production is based on a Ricardian technology with diminishing marginal product of labour owing to a fixed input, such as land or mineral resources. Labour is mobile between provinces and will be allocated up to the point where the after-tax wage rates and benefit from provincially provided public services are equalized across provinces. The equilibrium allocation of labour with costless mobility can be inefficient because individual workers do not take into account the fiscal externalities they impose, or provide, to existing residents when they move from one province to another. These fiscal externalities arise because if the provinces provide pure public goods, the migrant does not add to the cost of providing the public good in that province, but helps to finance it through the provincial taxes that he pays. This externality is diminished to the extent that the public services are impure public goods and in the limit it disappears if the provinces provide quasiprivate goods. This latter case seems to be the most relevant in the Canadian context because most provincial government spending is on health care, education and social assistance payments, which can be considered publicly provided private goods. The other source of fiscal

I For a comprehensive review of the literature on intergovernmental grants, see Robin Boadway and Anwar Shah, ed., Intergovernmental Fiscal Transfers (Washington, D.C.: The World Bank, 2007).

2 Bev Dahlby, "Notes on the Trade-Off between Efficiency and Fiscal Equity in a Federation with Imperfect Labour Mobility and Economic Rents" (Unpublished, School of Public Policy, University of Calgary, 2014).

3 Robin W. Boadway and Jean-Francois Tremblay, "Reassessment of the Tiebout Model," Journal of Public Economics 96 (2012): 1063-1078; Robin W. Boadway, “The Theory and Practice of Equalization,” CESifo Economic Studies 50 (2004): 211-254 
externality arises from provincial variations in the net fiscal benefits that workers can derive in different provinces because of differences in the source-based tax revenues - economic rents from provincial ownership or taxes on natural resources and source-based taxes on capital and differences in average incomes that give rise to differences in personal income tax bases. ${ }^{4}$ To the extent that labour is attracted to regions that provide these net fiscal benefits, the marginal products of labour will not be equalized across provinces and aggregate output will be reduced compared to an efficient allocation of labour that would equalize the marginal product of labour across provinces.

Within the context of this model, Boadway and Flatters derive formulas for equalization transfers that would neutralize the allocative inefficiencies that arise from provincial public good provision, differences in source-based revenues and differences in personal income tax bases. ${ }^{5}$ In addition to the efficiency gains from correcting distortions in the allocation of labour, Boadway and Flatters stress that an equalization grant system also promotes horizontal equity in the provision of public services at comparable levels of provincial taxation. They recognize that pursuing complete horizontal equity in a federation may conflict with the rationale for fiscal decentralization because of regional variations in economic and social conditions and preferences for public services. Another important reason for fiscal decentralization is to limit the concentration of political and fiscal powers of a central government and grant local control over key resources to local residents. In the author's view, decentralization reduces social conflicts that inhibit investment and economic growth and, most important, helps to preserve political liberties.

The allocative inefficiencies that the equalization transfers address in the Boadway and Flatters model arise from labour mobility. While labour is "reasonably mobile" in Canada, it is far from "perfectly mobile" owing to such factors as the social networks individuals have in their home provinces, as well as the transportation costs, re-location costs and the risks associated with moving to an unfamiliar labour market. ${ }^{6}$ To the extent that these mobility costs inhibit migration in response to differences in net fiscal benefits provided in different provinces, the regional misallocation of labour may be limited. Furthermore, housing prices may adjust to reflect differences in net fiscal benefits. If land in urban areas is relatively inelastic in supply, the efficiency losses from differences in the fiscal benefits among provinces may be limited. Other limitations of the Boadway and Flatters model, which will be discussed in more detail below, are the inadequate consideration given to the federal government in the model, as well as the insufficient descriptions of how federal transfers are financed and how provincial governments' fiscal decisions are affected by the equalization formula. In spite of these limitations, the Boadway and Flatters framework is still the starting point for most evaluations of the equalization system in Canada.

4 In "Evaluating the Efficiency and Equity of Federal Fiscal Equalization, David Albouy argues that differences in residence-based taxes should not be a source of transfers if workers are perfectly mobile across provinces. However, in Albouy's model, federal transfers are made to individuals and not to governments and therefore it has limited relevance for the evaluation of intergovernmental transfers.

5 Boadway (2004, p.230, equation (6)).

6 Kathleen Day and Stanley Winer, Interregional Migration and Public Policy in Canada: an Empirical Study, Carleton Library Series Vol. 223. (Montreal and Kingston: McGill-Queen's University Press, 2012); David Amirault, Daniel de Munnik, and Sarah Miller, "Explaining Canada's Regional Migration Patterns," Bank of Canada Review Spring (2013): 16-28; and Jonathan Bendiner, "Interprovincial Migration Shifts in Canada," Observation, TD Economics, June 17, 2013. 


\section{Horizontal and Vertical Fiscal Imbalances and the Marginal Cost of Public Funds}

Dahlby and Wilson try to provide a rationale for equalization transfers that does not rely on correcting allocative inefficiencies arising from labour mobility or based on notions of horizontal equity in the provision of public services and taxes across a federation. ${ }^{7}$ In keeping with other models of fiscal federalism, such as Zodrow and Miezkowski, ${ }^{8}$ Dahlby and Wilson assume that labour is completely immobile between provinces, but that there are differences in the size and tax sensitivity of the provincial tax bases. As a result, there are differences in the marginal cost of public funds for the provincial governments that want to raise a given amount of tax revenue. ${ }^{9}$

Drawing on the insights of the optimal taxation literature, the authors posit that the optimal allocation of taxes and public spending across provinces would equalize the marginal cost of public funds (MCF) in raising tax revenues and the social marginal benefit from the provision of public services. As further developed by Dahlby and Wilson, ${ }^{10}$ equalization grant formulas can be derived that contain both "needs" and "fiscal capacity" components.

Two insights are provided by looking at the rationale for equalization in this way. First, a province's fiscal capacity is its ability to raise revenues at a relatively low MCF, which in turn, depends on the tax rates, the tax sensitivity of the tax bases and the interactions among the province's tax bases. This implies that an accurate measure of a province's fiscal capacity depends not only on the size of its tax base (usually measured in per capita terms) but also on the tax sensitivity of that base and its complementarity or substitutability with others. For example, the provincial corporate income tax base is much more tax sensitive than the provincial sales tax base as capital flows are very sensitive to provincial and international tax differences. ${ }^{11}$ Sales tax bases, while affected by cross-border shopping and sales tax evasion, are less tax sensitive than corporate income tax bases.

7 Bev Dahlby and Leonard Wilson, "Fiscal Capacity, Tax Effort, and Optimal Equalization Grants," Canadian Journal of Economics 27, no. 3 (1994): 657-672. and see also Bev Dahlby “An Optimal Taxation Approach to Intergovernmental Grants.” Working paper 6, Department of Economics, University of Alberta, 2009.

8 George Zodrow and Peter Mieszkowski, "Pigou, Tiebout, Property Taxation, and the Underprovision of Local Public Goods," Journal of Urban Economics 19 (1986): 356-370.

9 The loss incurred by the private sector when the federal government raises an additional dollar of revenue through a tax rate increase generally exceeds a dollar because of the reallocation of resources in the economy to less productive uses as individuals and firms respond to the changes in the after-tax returns caused by the tax rate increase. The marginal cost of public funds, MCF, is a measure of the cost of raising an additional dollar of tax revenue. For a formal analysis of the MCF, see Bev Dahlby The Marginal Cost of Public Funds: Theory and Applications (Cambridge, MA: MIT Press, 2008). For a more intuitive explanation of the use of the MCF in cost-benefit analysis and the evaluation of tax reform proposals, see Bev Dahlby and Ergete Ferede, "The Effects of Tax Rate Changes on Tax Bases and the Marginal Cost of Public Funds for Canadian Provincial Governments," International Tax and Public Finance 19 (2012): 844-883.

10 Dahlby and Leonard Wilson, "Fiscal Capacity," 664, equation 8.

11 In Dahlby and Ferede's "The Effects of Tax Rate Changes on Tax Bases and the Marginal Cost of Public Funds for Canadian Provincial Governments," the greater tax sensitivity of the provincial corporate income tax bases compared to the sales tax bases is reflected in the much higher MCFs for corporate income tax than for provincial sales taxes. 
Dahlby and Wilson show that the Representative Tax System (RTS) formula for equalization transfers, which is the basis for calculating equalization payments in Canada, can only be derived from their "optimal equalization" formula if all of the tax bases in the formula exhibit the same degree of tax sensitivity (which, as the preceding discussion indicates, is highly unlikely). They view the RTS system for calculating equalization grants as an approximation to the optimal equalization transfers in the absence of accurate estimates of the tax sensitivities of the tax bases. ${ }^{12}$

In addition to this insight concerning how fiscal capacity should be defined and measured, viewing equalization grants through the lens of the optimal taxation literature provides a way of defining the slippery concept of fiscal imbalance. As discussed at greater length by the author elsewhere, ${ }^{13}$ a horizontal fiscal imbalance in a federation can be defined as occurring when the social marginal cost of public funds varies across provinces and a vertical fiscal imbalance occurs when the social marginal cost of public funds varies across levels of government. Defining horizontal and vertical fiscal imbalances in this way integrates these notions with the normative theory of optimal taxation and provides a basis for evaluating fiscal transfers between levels of government. In particular, it implies that there will be a vertical fiscal gap in most federations (i.e., the central government will raise more tax revenues than it needs to fund its own expenditures and that it will transfer revenues to provincial governments). This fiscal gap is needed to equalize, or at least reduce the difference, in the marginal cost of public funds between the federal government and the provincial governments. The underlying rationale for such transfers is that tax bases are generally more sensitive at the provincial level than they are at the federal level owing to the fact it is easier to shift activity across provincial boundaries in response to a tax rate increase than it is across international boundaries. In this sense, a federation that has a vertical fiscal balance will generally be one in which there is a positive fiscal gap (i.e., subnational governments will spend more than they raise in own-source tax revenues and the difference will be financed by transfers from the central government).

While providing some insights into the rationale for fiscal transfers in a federation, the optimal taxation approach has practical limitations because of our limited knowledge of the parameters that reflect tax sensitivities of tax bases. Also, the models developed by Dahlby and Wilson ${ }^{14}$ ignore the incentive effects that would be created by the transfer formula and the interactions between the federal and provincial governments' tax policies given that both levels of government impose taxes on the same personal, corporate, sales and excise tax bases.

12 For estimates of the tax sensitivities of the provincial personal income, corporate income and sales tax bases, see Dahlby and Ferede, "The Effects of Tax Rate Changes," 844-883.

13 Bev Dahlby “An Optimal Taxation Approach to Intergovernmental Grants.” Working paper 6, Department of Economics, University of Alberta, 2009. Dahlby, The Marginal Cost of Public Funds, chapter 9.

14 Bev Dahlby, "An Optimal Taxation Approach to Intergovernmental Grants" (Working paper 6, Department of Economics, University of Alberta, 2009). 


\section{Regional Shocks and Fiscal Insurance}

Providing provinces with insurance against adverse fiscal shocks has never been the principal motivation for the equalization program. Indeed, a program that has provided funds to the Maritime provinces and Quebec every year since its inception over 50 years ago can hardly be classified as an insurance scheme. Other provinces, however, such as Saskatchewan and British Columbia have cycled in and out of the program. For the last few years, Ontario has become a recipient while Newfoundland is no longer a recipient. Thus eligibility for equalization does depend on the positive and negative shocks to the provincial economies.

Using a framework that is similar to that of Dahlby and Wilson, Boadway and Tremblay develop a model of an optimal equalization program in which labour is completely immobile between provinces and the provincial and federal governments use distortionary taxes to raise revenues. ${ }^{15}$ The Boadway and Tremblay model contains a vertical fiscal externality owing to the fact that the federal and provincial governments both levy taxes on the same base and provincial tax bases are subject to random shocks. In particular, a higher provincial tax rate erodes both the federal and provincial tax base, leading to lower federal revenues. This vertical tax externality implies that provincial governments that have not suffered a negative shock will underestimate the marginal cost of public funds and over-provide public services. Under the optimal fiscal policy, federal public goods are under-provided compared to those in a unitary state because a lower federal tax rate reduces the distortion caused by vertical tax externality. The equalization grant to a province that has suffered a negative shock is also set below the level that would equalize the marginal cost of public funds between the provinces in order to lower the federal tax rate. Therefore, the province with the negative shock would have a higher MCF of funds than the province with the positive shock. In other words, because of the vertical tax externality arising when federal and provincial governments utilize the same tax base, the optimal equalization program would not eliminate the horizontal fiscal imbalances that arise when some provinces are subject to negative economic shocks, contradicting Dahlby and Wilson's conjecture that the MCFs would be equalized.

Boadway and Tremblay also demonstrate that if the federal government cannot commit to this optimal equalization program, and instead provides more generous transfers to a province in the event of a negative shock, then the MCFs will be equalized across provinces and provincial expenditures will be excessive. One important caveat to the Boadway and Tremblay result is that the equalization transfer in their model is a lump sum and that it is not determined by a formula such as the RTS formula. Smart has shown that such formulas reduce the perceived MCFs of the equalization recipient provinces and they may be lower than that of the nonrecipient province. ${ }^{16}$ Admittedly, this makes it difficult to determine the extent and direction of the horizontal fiscal imbalances based on the provinces' perceived MCFs.

15 Robin Boadway and Jena-Francois Tremblay, Reassessment of the Tiebout Model," Journal of Public Economics 96 (2012): 1063-1078.

16 Michael Smart, "Taxation and Deadweight Loss in a System of Intergovernmental Transfers," Canadian Journal of Economics 31, no. 1 (1998): 189-206. 


\section{The Trade-Off between Efficiency and Fiscal Equity}

Two key assumptions underlie the Boadway and Flatters model that equalization transfers are required to achieve an efficient regional allocation of labour. One is that the provincial publicly provided goods and services have some degree of "publicness". Second, the production technology exhibits decreasing returns to labour in all provinces because of a fixed input such as land or resources. Dahlby presents a model where these two assumptions are relaxed. ${ }^{17}$ The justification for relaxing the first assumption is that most provincial expenditures are on health care, education and social services, which can be characterized as quasi-private goods. Second, the assumption of diminishing returns for an entire regional economy exaggerates the importance of fixed inputs that give rise to economic rents because the resource sectors are highly capital intensive and directly employ only a small fraction of the labour force in the resource-rich regions.

Dahlby's model is based on Boadway and Tremblay's model ${ }^{18}$ of imperfectly mobile labour in a federation where subnational governments (provinces) levy distortionary taxes to finance their expenditures. One of the provincial governments receives economic rent, whereas in the Boadway and Tremblay model, economic rents are received directly by workers in one of the provinces. The Dahlby model shows that an increase in economic rent received by a province results in a Pareto improvement (i.e., both residents of the province that receives the economic rent and residents of the other non-rent receiving provinces are better off as a result of a vertical tax externality). The provincial government in the province that receives the economic rents lowers its distortionary taxes, resulting in an expansion of the income tax base that allows the federal government to lower its tax rates and maintain the same federal tax revenue. In this model, therefore, there is no efficiency rationale for a fiscal transfer or equalization program as in the Boadway and Flatters model. However, the economic rent received by one province creates a fiscal imbalance between the two provinces. In this context, Dahlby analyzes the effects of an equalization system with the objective of achieving fiscal equality. The framework developed in this model is used to calculate the efficiency losses from the equalization program in The Inclusion Rate for Resource Revenues section of this paper, found on page 16.

\section{AN OVERVIEW OF THE CANADIAN EQUALIZATION SYSTEM}

We begin by providing an overview of the Canadian equalization system as well as the other major federal transfers to the provinces, the Canada Health Transfer (CHT) and the Canada Social Transfer (CST). We document the conventional measures of a province's fiscal capacity, both with and without federal transfers. We then examine the trends in the dispersions of provincial tax rates and per capita expenditures. This section provides the backdrop to the analysis of policies to reform the equalization system.

\footnotetext{
17 Dahlby, "Notes on the Trade-Off between Efficiency and Fiscal Equity."

18 Robin Boadway and Jean-Francois Tremblay, "Mobility and Fiscal Imbalance," National Tax Journal 63, no. 4 part 2 (2010): 1023-54.
} 


\section{Fiscal Capacity Measures Used for Equalization}

The conventional way to measure fiscal capacity has been to calculate the amount of revenue per capita that a province could obtain from its main tax bases - personal income, business income, consumption and property - if it imposed the national average tax rates on bases. Provincial resource revenues are also included in the measures of fiscal capacity. Figure 1 shows these measures of the provinces' fiscal capacities in 2011-12.

\section{FIGURE 1 PER CAPITA YIELD AT NATIONAL AVERAGE TAX RATES, 2011-12}

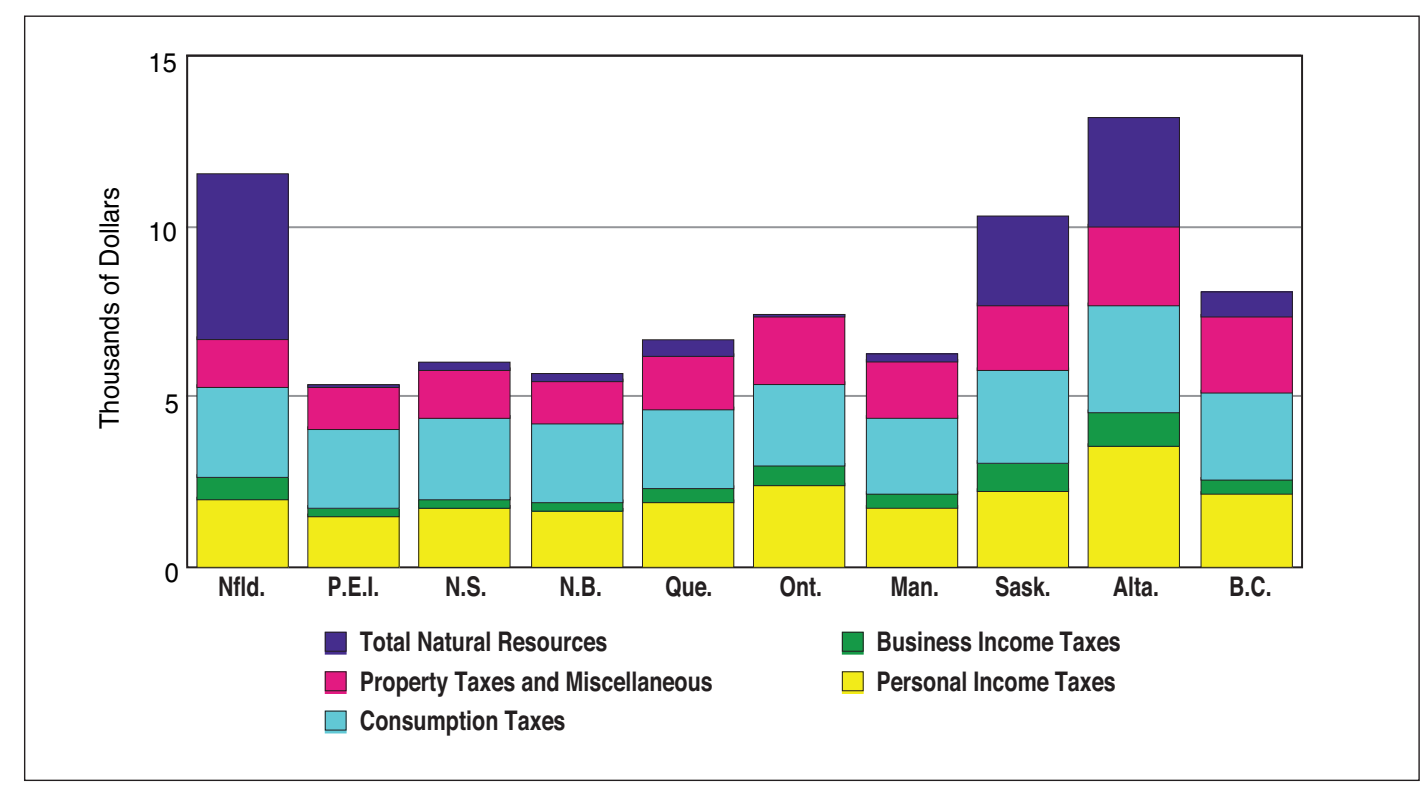

By these measures, Alberta had the highest fiscal capacity at $\$ 13,187$, while Prince Edward Island (P.E.I.) had the lowest at $\$ 5,315$. Resource revenues represent over 40 per cent of Newfoundland and Labrador's measured fiscal capacity, and they are also significant components of the fiscal capacity measures of Alberta (23 per cent), Saskatchewan (25 per cent) and to a lesser extent British Columbia (8 per cent). These measures of fiscal capacity are the basis for calculating the entitlements for equalization (unlike the other measures, only 50 per cent of resource revenues are included in the formula). Since 2009, entitlements have been subject to a cap imposed by the federal government to limit the total amount of equalization payments.

Entitlements to equalization are calculated on the basis of a province's fiscal deficiencies with respect to the five revenue sources. Figure 2 shows these deficiencies based on the data for 2011-12. Provincial governments with above average fiscal capacities do not receive equalization entitlements. Nor, it is important to note, do they contribute to the funding of equalization payments. Alberta is the only province that has surplus fiscal capacities with respect to all five revenue sources. P.E.I., Nova Scotia, New Brunswick, Quebec and Manitoba have fiscal deficiencies with respect to all five revenue sources. Newfoundland and Labrador has an overall surplus fiscal capacity because of its substantial resource revenues. Ontario has a fiscal deficiency with respect to resource revenues and consumption taxes. In the absence of the equalization of resource revenues, Ontario would not be eligible for equalization payments. In the case of Quebec and the Maritime provinces, personal income and property taxes deficiencies are the largest contributors to equalization entitlements. 
FIGURE 2 PER CAPITA DEFICIENCY (+) OR EXCESS (-) FISCAL CAPACITY IN RELATION TO THE 10 PROVINCE STANDARD IN 2011-12

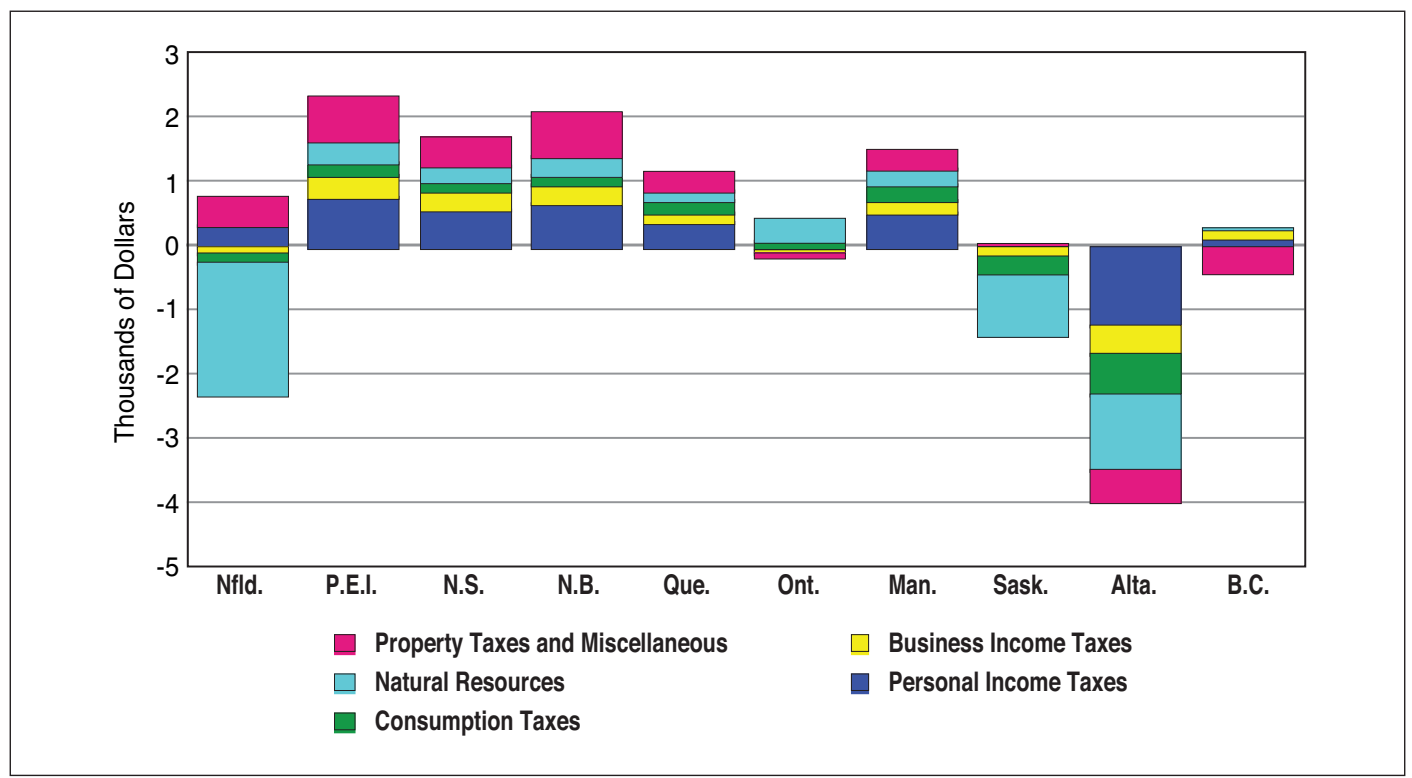

Table 1 shows the equalization payments to the provinces since 2000-01. Six provinces representing 71 per cent of the Canadian population received equalization payments totalling \$16.1 billion dollars in 2013-14. Canada's two largest provinces, Ontario and Quebec, received 20 per cent and 49 per cent of the equalization payments respectively. In per capita terms, P.E.I. was the largest recipient province, receiving $\$ 2,317$. Quebec and Ontario, by way of comparison, received $\$ 966$ and $\$ 232$ respectively per capita.

\section{TABLE 1 TOTAL EQUALIZATION PAYMENTS BY PROVINCE}

\begin{tabular}{|l|r|l|l|l|l|r|r|r|r|r|l|}
\hline & \multicolumn{1}{|c|}{ Nfld. } & P.E.I. & N.S. & N.B. & Que. & Ont. & Man. & Sask. & Alta. & B.C. & Total \\
\hline $2000-01$ & 1,112 & 269 & 1,404 & 1,260 & 5,380 & 0 & 1,314 & 208 & 0 & 0 & 10,948 \\
$2001-02$ & 1,055 & 256 & 1,315 & 1,202 & 4,679 & 0 & 1,362 & 200 & 0 & 240 & 10,310 \\
$2002-03$ & 875 & 235 & 1,122 & 1,143 & 4,004 & 0 & 1,303 & 106 & 0 & 71 & 8,859 \\
$2003-04$ & 766 & 232 & 1,130 & 1,142 & 3,764 & 0 & 1,336 & 0 & 0 & 320 & 8,690 \\
$2004-05$ & 762 & 277 & 1,313 & 1,326 & 4,155 & 0 & 1,607 & 772 & 0 & 682 & 10,894 \\
$2005-06$ & 861 & 277 & 1,344 & 1,348 & 4,798 & 0 & 1,601 & 89 & 0 & 590 & 10,907 \\
$2006-07$ & 687 & 291 & 1,386 & 1,451 & 5,539 & 0 & 1,709 & 13 & 0 & 459 & 11,535 \\
$2007-08$ & 477 & 294 & 1,465 & 1,477 & 7,160 & 0 & 1,826 & 226 & 0 & 0 & 12,925 \\
$2008-09$ & 0 & 322 & 1,465 & 1,584 & 8,028 & 0 & 2,063 & 0 & 0 & 0 & 13,462 \\
$2009-10$ & 0 & 340 & 1,391 & 1,689 & 8,355 & 347 & 2,063 & 0 & 0 & 0 & 14,185 \\
$2010-11$ & 0 & 330 & 1,110 & 1,581 & 8,552 & 972 & 1,826 & 0 & 0 & 0 & 14,372 \\
$2011-12$ & 0 & 329 & 1,167 & 1,483 & 7,815 & 2,200 & 1,666 & 0 & 0 & 0 & 14,659 \\
$2012-13$ & 0 & 337 & 1,268 & 1,495 & 7,391 & 3,261 & 1,671 & 0 & 0 & 0 & 15,423 \\
$2013-14$ & 0 & 340 & 1,458 & 1,513 & 7,833 & 3,169 & 1,792 & 0 & 0 & 0 & 16,105 \\
\hline
\end{tabular}

Source: Department of Finance Public Tables December 2012.

Note: Table includes payments and additional amounts. Does not include the Total Transfer Protection provided between 2010-11 and 2013-14. Does not include 2009-10 transition adjustment to N.S. 
The other major transfers from the federal government to the provinces are the CHT and the CST ( $\$ 30.2$ billion and $\$ 12.2$ billion respectively in 2013-14), which evolved out of federal matching grant programs in the 1960s to assist the provinces in the provision of health care services, post-secondary education and social assistance programs. These programs have evolved into block grants with only general restrictions on their use or entitlement (e.g., adherence to the principles of the Canada Health Act). Their historical origins, however, are reflected in their names, and the provinces often compare their health care spending with the magnitude of the CHT even though the basis for this comparison becomes less and less salient with the passage of time, especially given the provinces' constitutional responsibility for the vast majority of publicly provided health care services.

The CST is an equal per capita grant to the provinces of $\$ 347$ in 2013-14, which is scheduled to grow at three per cent annually. The CHT will be an equal per capita grant starting in 201415. In December 2011, the federal government announced that the CHT will grow at six per cent a year until 2016-17. Then, starting in 2017-18, the CHT will grow at a three-year moving average of nominal GDP growth, with a minimum increase of three per cent per year for subsequent years. Figure 3 shows the relative sizes of the three main block transfers to the provinces in 2013-14.

FIGURE 3 THE THREE MAJOR BLOCK GRANT PROGRAMS IN 2013-14

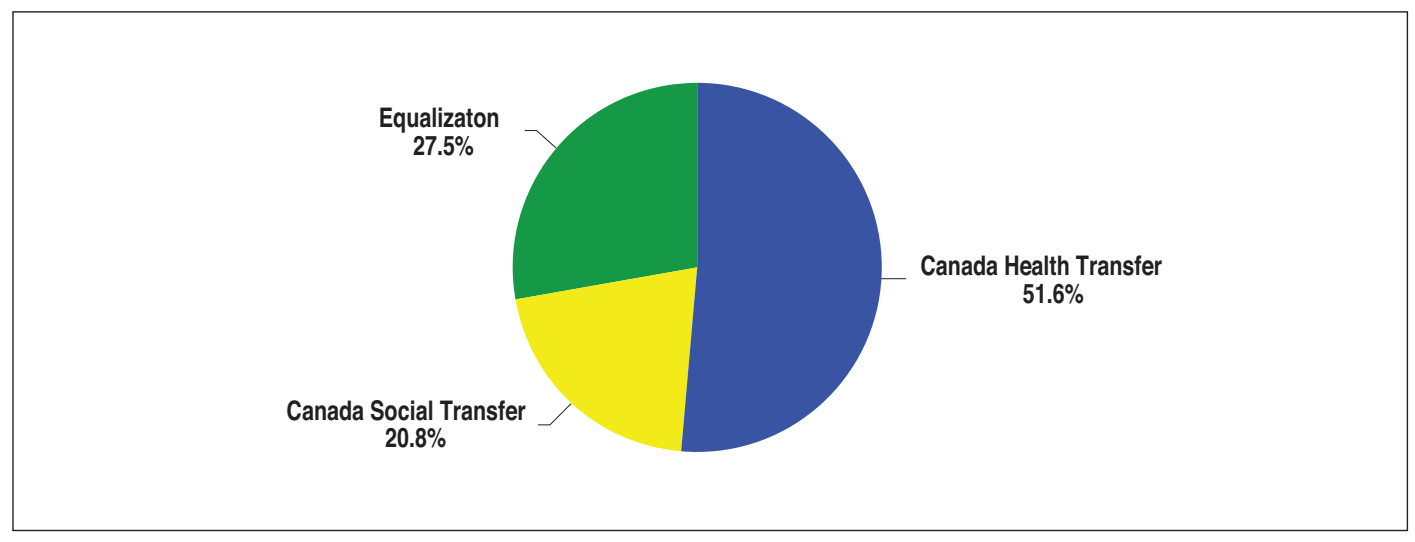

Figure 4 shows the per capita transfers to the provinces under the three major block transfer programs in 2013-14. The combined average per capita CHT and CST was \$1206 in 2013-14. While equalization is only 27.5 per cent of the total federal block transfers to the provinces, it is almost two-thirds of the total federal transfer to P.E.I. and New Brunswick, more than 50 per cent of the total block transfer to Nova Scotia and Manitoba and the largest component of the federal transfer to Quebec. 


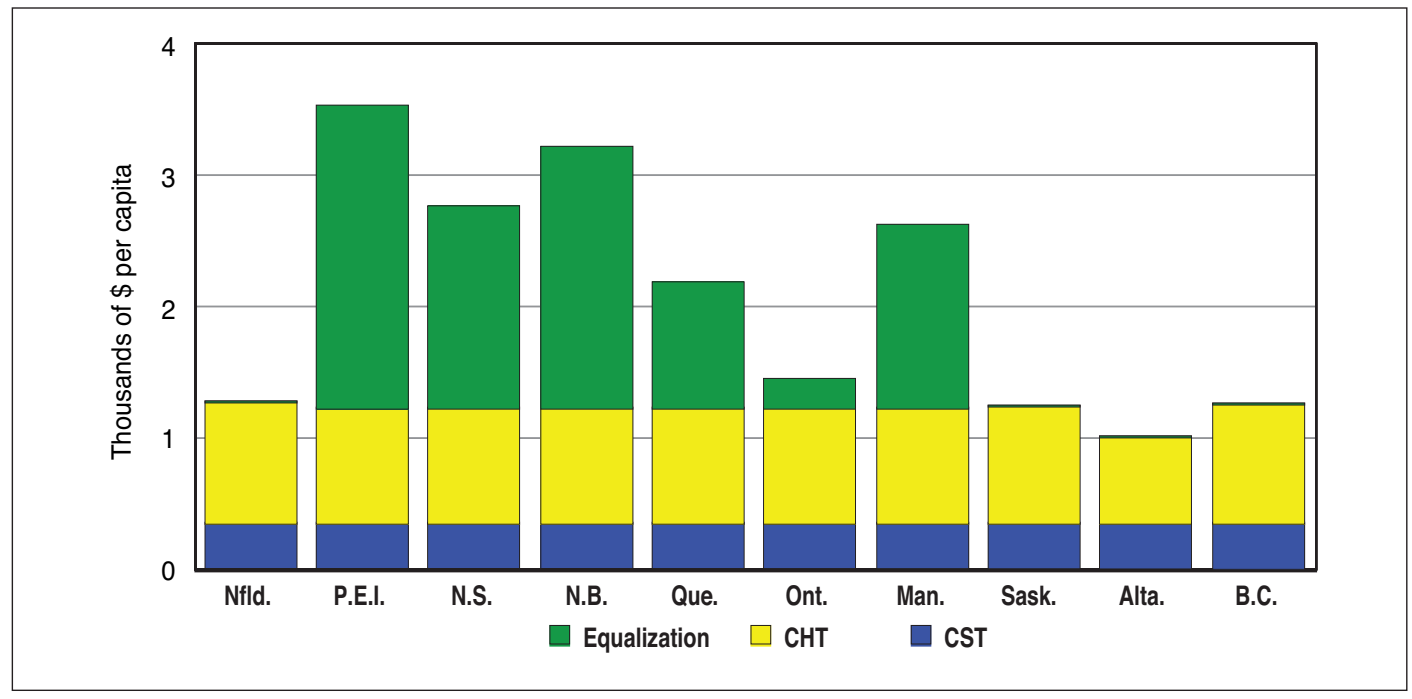

A more complete picture of the fiscal capacities of the provinces emerges when we combine the own-source measures of fiscal capacity in Figure 1 with the per capita transfers in Figure 4.

\section{FIGURE 5 MEASURES OF FISCAL CAPACITY FROM OWN SOURCE REVENUES AND FEDERAL BLOCK TRANSFERS IN 2011-12}

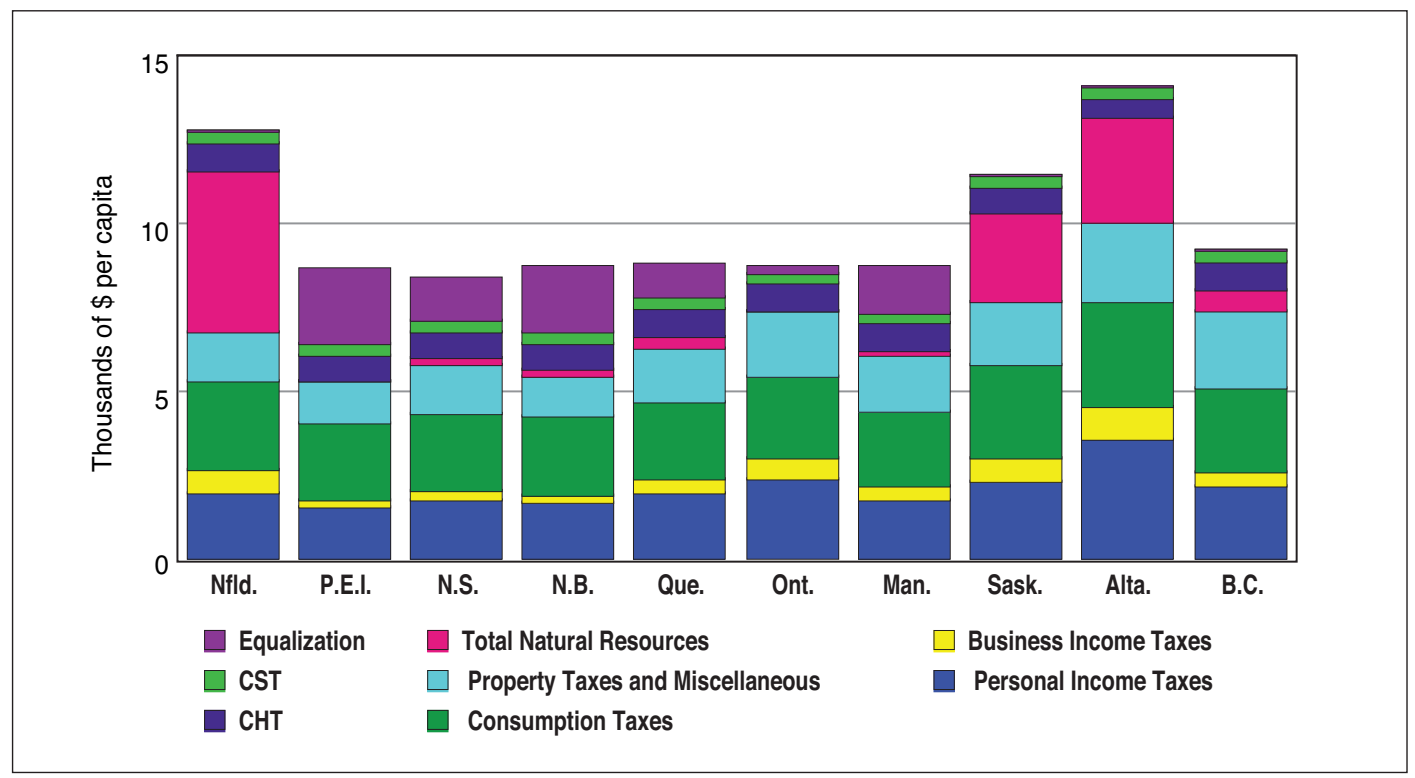

Combining federal transfers and own-source revenues, the average per capita revenue capacity of the provinces in $2011-12$ is $\$ 9,978$, ranging from $\$ 14,115$ in Alberta to $\$ 8,397$ in P.E.I. The coefficient of variation - the ratio of the standard deviation to the mean expressed as a percentage - of the revenue capacity measures of the provinces was 20.6 per cent. 


\section{Tax Rate Disparities}

Have the fiscal disparities among the provinces increased in recent years? We begin by examining the trend in summary measures of the variation in the tax rates imposed on the main provincial tax bases. Figure 6 shows the trend in the coefficient of variation $(\mathrm{CoV})$ and the range of the top marginal personal income tax rates imposed by the provinces over the period 1972 to 2011.

\section{FIGURE 6 COEFFICIENT OF VARIATION AND RANGE OF THE TOP MARGINAL PROVINCIAL INCOME TAX RATES}

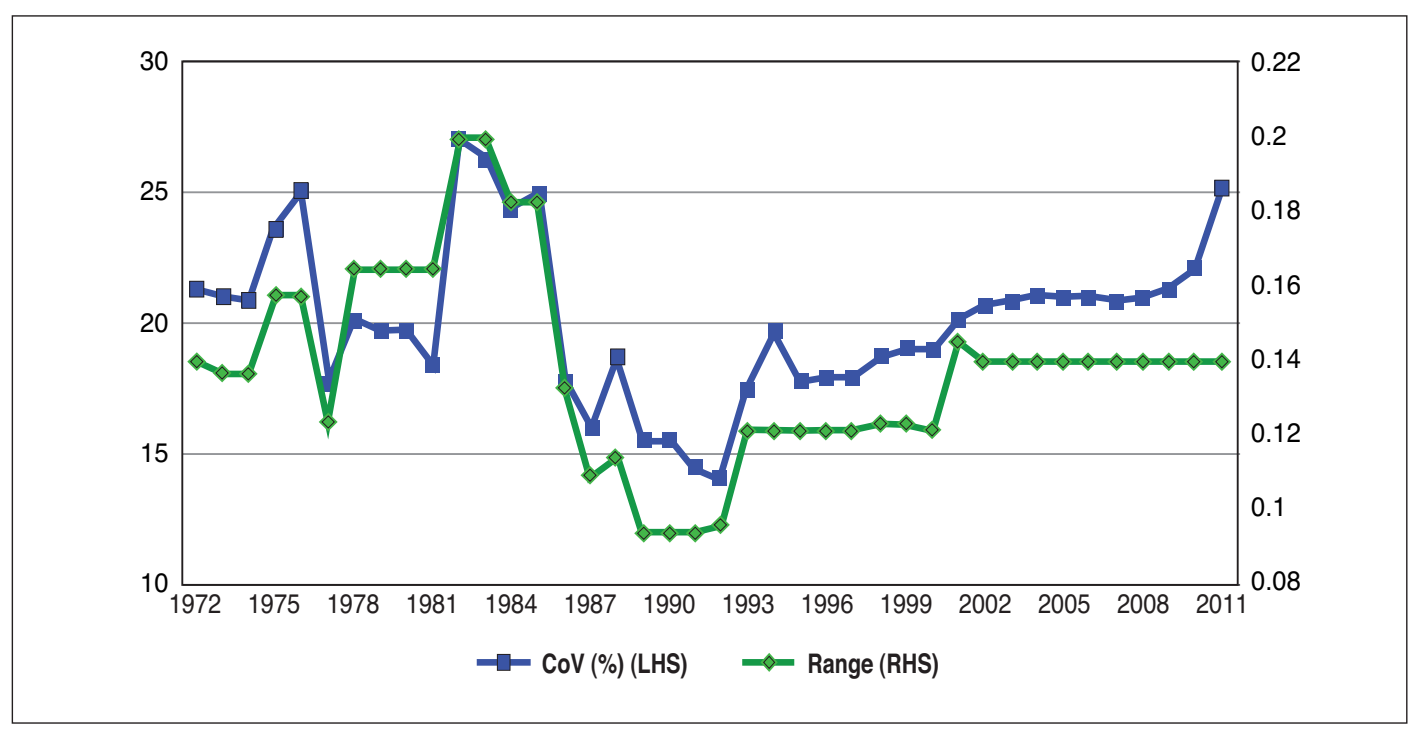

The figure shows that the variation in top marginal provincial personal income tax rates was high in the mid-1970s and mid-1980s and then declined to a low point in the early 1990s. This is consistent with the trend in oil and natural gas prices, which were high from the mid-70s to the mid-80s and then declined after 1985. Since the mid-1990s, there has been a steady upward trend in the coefficient of variation in provincial personal income tax rates such that by 2011 the degree of variation was comparable to the variation in the mid-70s and mid-80s. Broadly speaking, the variation in personal income tax rates follows a pattern that is consistent with more variation occurring when resource revenues are high. Other factors besides the size of resource revenues, of course, influence the variation in tax rates, including the level and distribution of federal transfers to the provinces.

Since provincial variations in corporate income tax (CIT) rates may influence the allocation of capital across the provinces, monitoring the trend is of special significance. Figure 7 shows the coefficient of variation and range of the provincial general CIT rates over the 1972-2011 period. As with the personal income tax, the variation in CIT rates was high in the mid-1980s and then declined to a relatively low variation in the mid-1990s. The variation remained relatively constant until 2008 and then has increased in 2010 and 2011 to the highest levels observed since 1990 . 


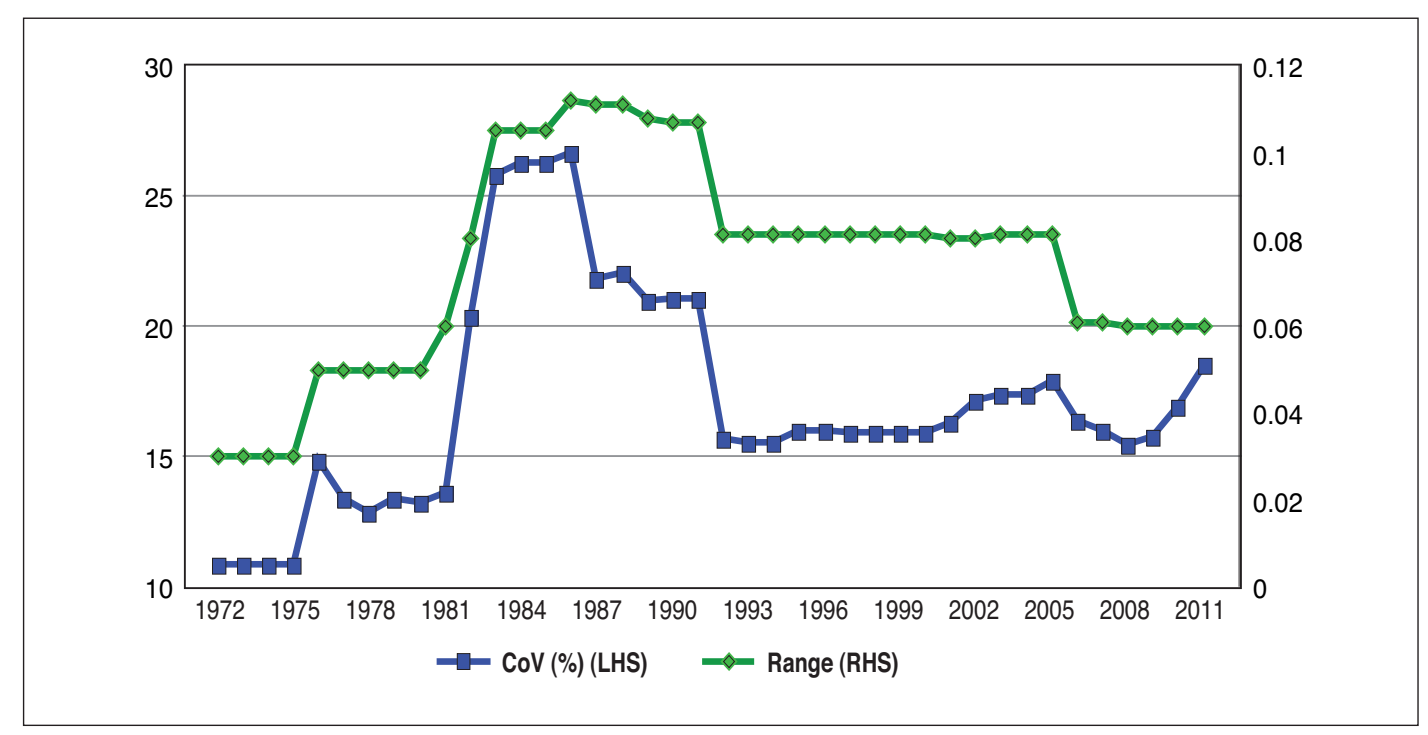

Figure 8 shows the coefficient of variation and the range of provincial sales tax rates between 1972 and 2011. The variation in rates climbed abruptly from the mid-1970s, peaked in 1981, followed by a slow convergence in rates that continued until 2006. Although there has been an increase in the variation in provincial sales tax rates in recent years, the variation is small and still lower than at any time since the mid-1990s.

\section{FIGURE 8 COEFFICIENT OF VARIATION AND RANGE OF THE PROVINCIAL SALES TAX RATES}

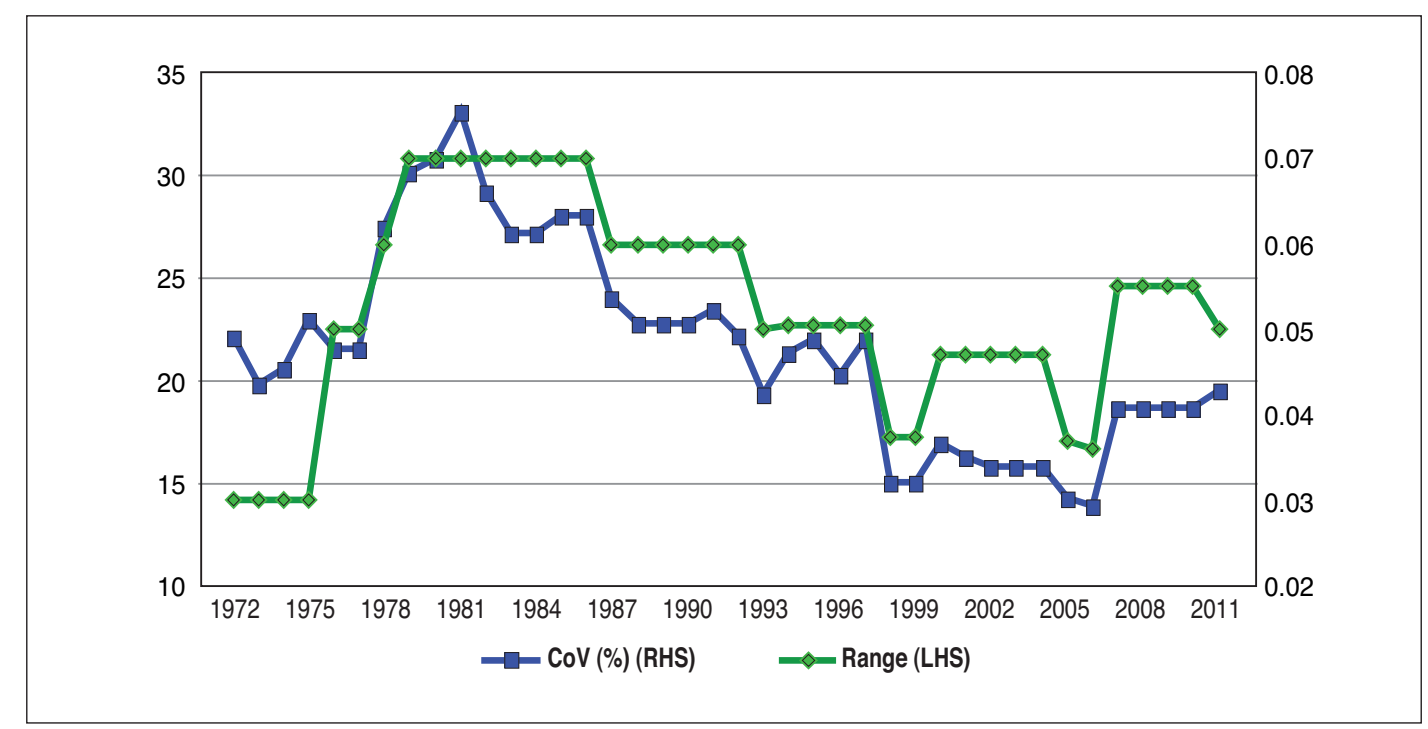


FIGURE 9 COEFFICIENTS OF VARIATION IN THE PROVINCIAL PERSONAL INCOME TAX, CORPORATE INCOME TAX, AND SALES TAX RATES

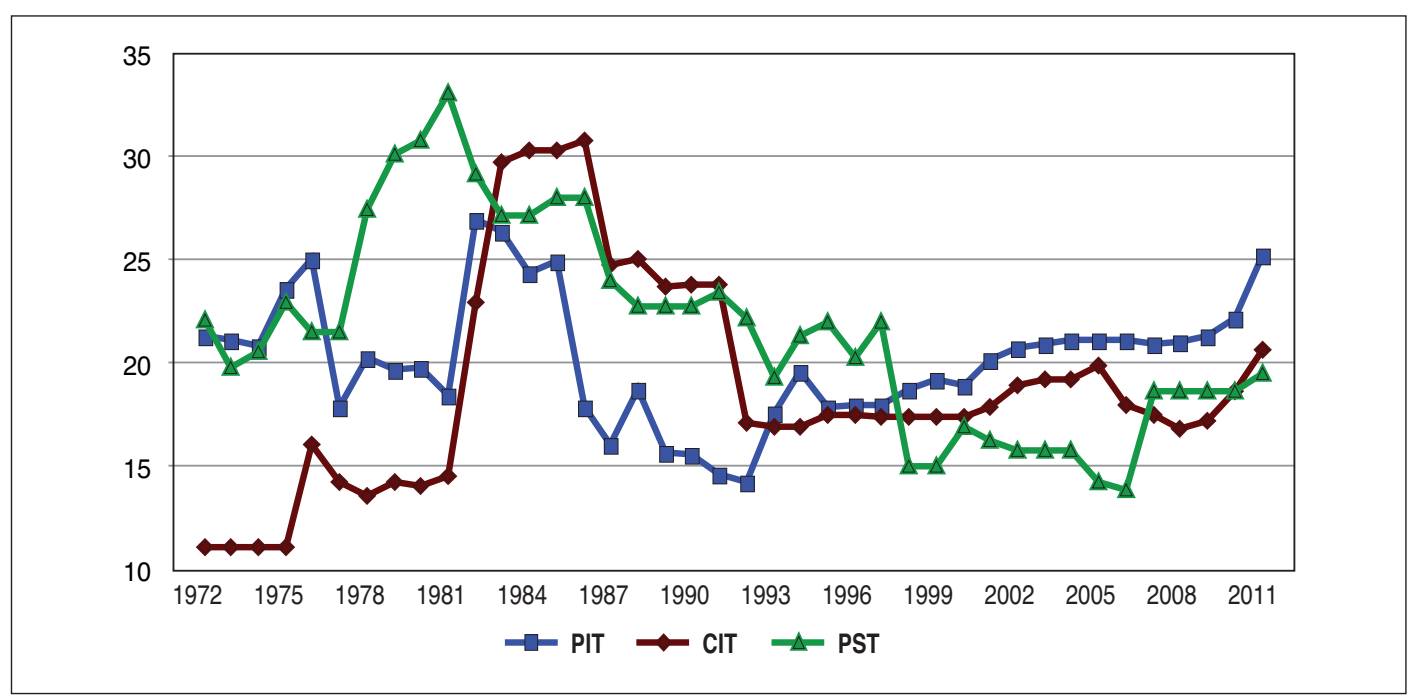

Figure 9 shows that the variation in each of the three tax rates peaked in the mid-1970s to mid1980s during a period of relatively high resource revenues. In the years that followed, there was a general decline in the variations in rates. While this decline ended in the early 1990s for provincial personal income tax (PIT) rates, it continued until the mid-2000s for provincial sales tax (PST) rates. The variation in PIT rates is now comparable to the variation in the mid-1980s. While there have been recent increases in the variation in the CIT and PST rates, the degree of variation is substantially lower than in the $1975-85$ period for the PST and the $1980-85$ period for the CIT.

\section{Spending Disparities}

We now turn to the dispersion in provincial spending. Comparable data on provincial and local government spending are currently only available from Statistics Canada for the 1981-2009 period. Figure 10 shows the trend in the coefficient of variation per capita total expenditures of the provincial and local governments over this time period. For comparative purposes, we have also plotted the coefficient of variation of the PIT rates. 


\section{FIGURE 10 COEFFICIENTS OF VARIATION IN PROVINCIAL AVERAGE PER CAPITA EXPENDITURES AND PROVINCIAL PERSONAL INCOME TAX RATES}

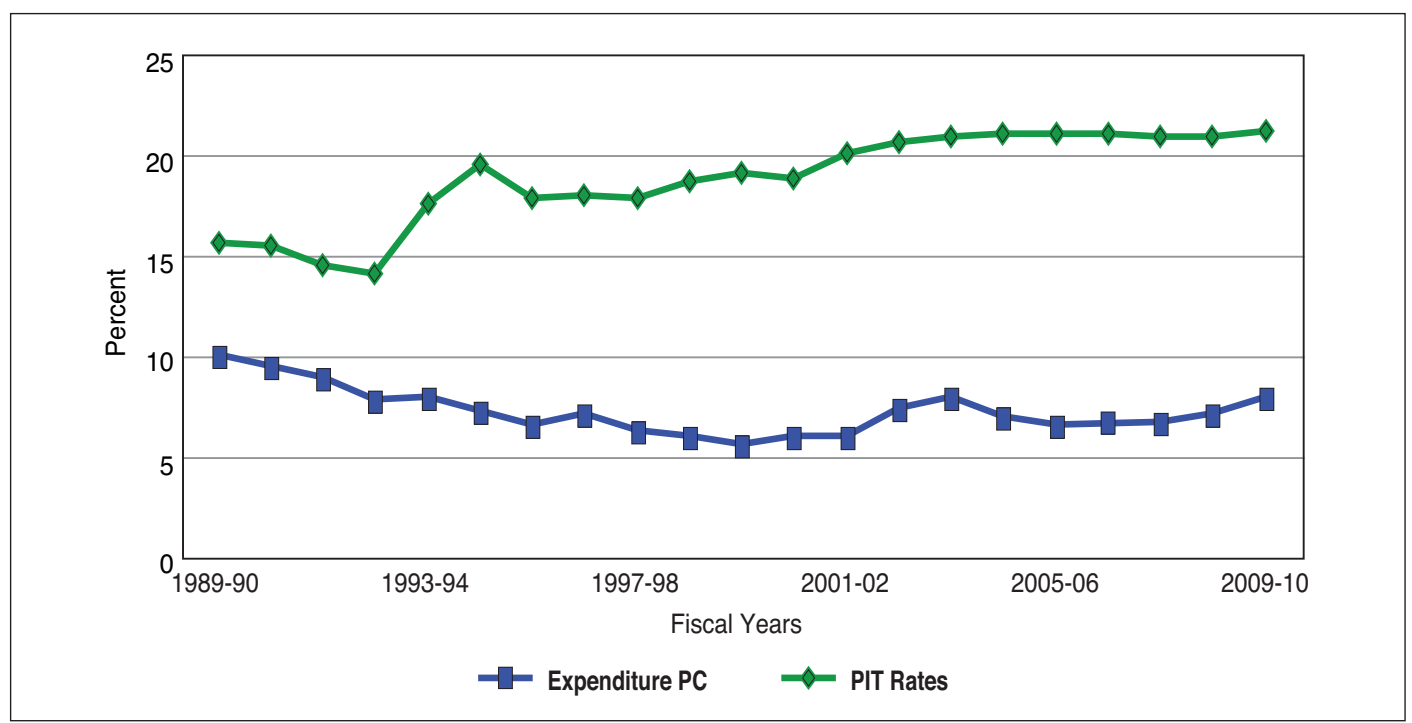

As the variation in per capita expenditures fell in the 1989-2000 period, the variation in personal income tax rates rose. While variation in per capita expenditures gradually increased in the 2000-10 period, it was still lower in 2009-10 than it was in 1989-90, meaning the degree of dispersion in spending was within historical bounds. Another point to notice is that the variation in provincial per capita expenditures is considerably lower that the dispersion in provincial income tax rates. This is consistent with the predictions of the model used by Dahlby that a resource-rich province will use its resource revenues to lower its tax rates, while the recipient provinces will adopt relatively high tax rates because the equalization formula compensates them for the reductions in their tax bases when they increase their tax rates. ${ }^{19}$ This effectively reduces their perceived MCFs, inducing them to finance relatively high expenditures at relatively high tax rates.

Finally, Figure 11 shows that average annual growth rate of provincial and local government expenditures over the period 1989-90 to 2009-10. At 3.99 per cent, Newfoundland and Labrador experienced the highest growth rate, while Alberta experienced the lowest (2.87 per cent). In terms of levels of expenditures, Newfoundland and Labrador had the highest per capita in 2009-10 at $\$ 14,008$, followed by Saskatchewan $(\$ 13,936)$, Quebec $(\$ 13,751)$ and Alberta $(\$ 13,415)$. Ontario had the lowest per capita expenditure rate $(\$ 11,307)$.

\footnotetext{
19 Dahlby, "Notes on the Trade-Off between Efficiency and Fiscal Equity."
} 
FIGURE 11 AVERAGE ANNUAL GROWTH RATES OF PROVINCIAL AND LOCAL GOVERNMENT PER CAPITA EXPENDITURES, 1989-90 TO 2009-10

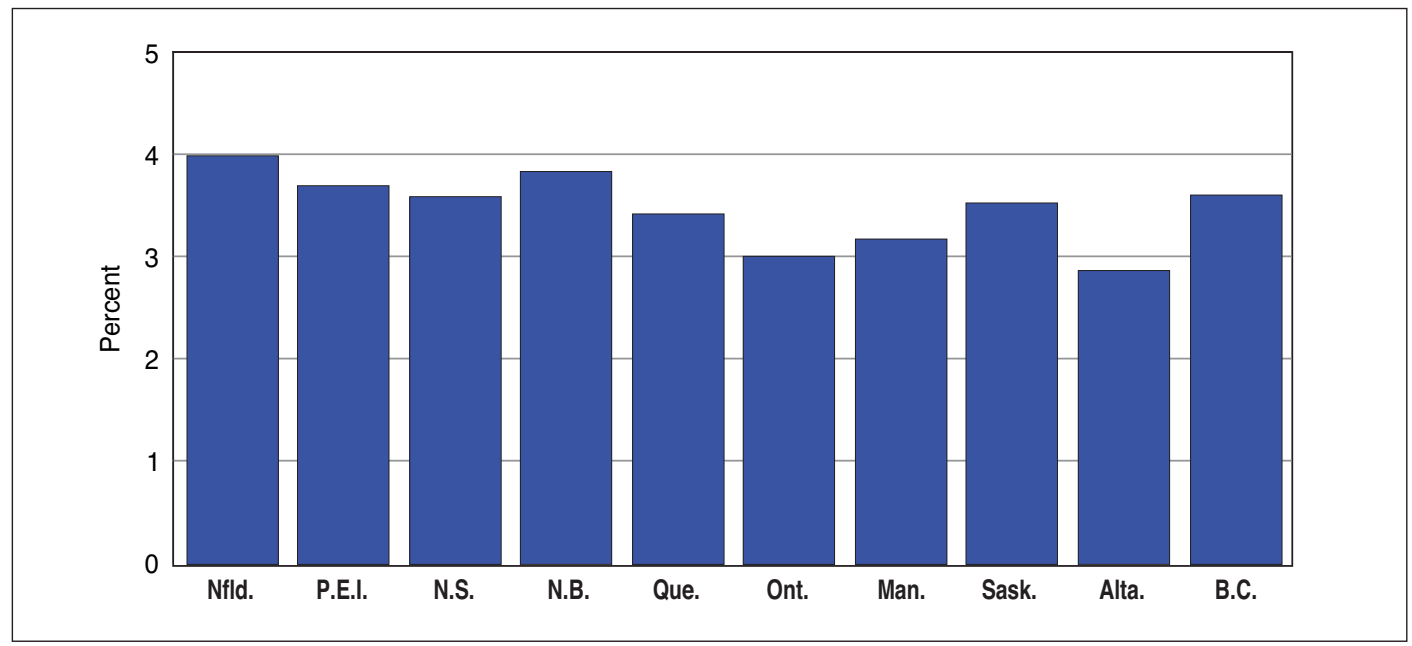

\section{ISSUES IN THE REFORM OF THE EQUALIZATION PROGRAM}

In this section of the paper, we examine the prominent proposals for equalization reform that have been put forward by commentators and provincial governments. We begin with a discussion of the inclusion rate for resource revenues in the computation of equalization entitlements. Then, on page 22, we discuss the removal of the ceiling on total equalization grants. In the following subsection, we consider the proposal to exempt entitlements that are deposited in provincial social welfare funds from the calculation of equalization. Next, we examine a proposal to reduce the CHT and the CST to provinces with above average fiscal capacities. In the subsection on page 27 , we consider incorporating variations in costs and needs in the computation of the equalization entitlements by reviewing the Gusen (2012) prototype needs based system. We conclude the section by briefly noting some other fiscal reforms that have been paired with the reform of the equalization system.

\section{The Inclusion Rate for Resource Revenues}

The inclusion rate for natural resource revenues is one of the most important and controversial aspects of the equalization system. The average provincial per capita fiscal capacity from resource revenue in 2011-12 was $\$ 695$, which was only a quarter of the personal income tax and consumption fiscal capacity measures. However, resource revenues are concentrated in three provinces - Newfoundland and Labrador, Saskatchewan and Alberta - and this implies that a substantial proportion of the equalization entitlements can be driven by the resource revenues. For example, using the 2011-12 figures for fiscal capacity, total equalization entitlements would have been $\$ 24.2$ billion with a 100 per cent inclusion rate, $\$ 17.8$ billion with a 50 per cent rate, $\$ 14.5$ billion with a 25 per cent rate and $\$ 12.8$ billion if resource revenues were excluded from the calculation altogether. In other words, a 50 per cent inclusion rate reduces total equalization entitlements by about 25 per cent compared to entitlements with a 100 per cent inclusion rate. 
Thus the inclusion rate has a significant effect on the total quantum of equalization (assuming no aggregate cap on equalization payments) and substantial effects on the entitlements of individual provinces. If resource revenues were not included in the equalization formula, for example, Ontario would not receive equalization. Given its importance, it is not surprising that the inclusion rate has been the focus of much of the debate concerning reforms to the equalization system. For example, the Drummond Commission recommended that Ontario "advocate for reforms to Equalization by, at a minimum, fully capturing resource revenues..."20

The Expert Panel Report recommended that the federal government adopt a 50 per cent inclusion rate rather than full inclusion not over affordability concerns, but because, as Paul Boothe noted, "it flowed from the principle that provinces should enjoy some net benefit from their ownership of resources - even if they were recipients of Equalization payments."21 Calculations based on the 2011-12 fiscal capacities illustrate how the inclusion rate affects a province's net benefit from its resource revenues. For example, with a 100 per cent inclusion rate, New Brunswick's fiscal capacity would only increase $\$ 2.20$ if it received an extra $\$ 100$ per capita in resource revenues - an effective claw-back rate of 97.8 per cent. For Quebec, the claw-back rate would be 76.7 per cent.

Between the costs resource development impose on the provinces and their control over royalty, pricing and general development policies, it is clear that a 100 per cent inclusion rate, as recommended by the Drummond Commission, would create a severe disincentive for resource development and revenue collection by the recipient provinces. The claw-back rate declines in proportion to the inclusion rate. A 50 per cent inclusion rate, therefore, still represents a 48.9 per cent claw-back rate for New Brunswick and a 38.4 per cent claw-back rate for Quebec. One of the challenges that policy makers face when determining the inclusion rate is balancing the incentive effects on provincial resource development and pricing policies against narrowing the disparities in provincial fiscal capacities. Another challenge concerns the federal financing of equalization entitlements. Without directly contributing anything to its coffers, higher resource revenues increase the amount (in the absence of an aggregate cap) the federal government must pay in equalization, leaving Ottawa to finance the payments from its general revenues - principally its personal and corporate income revenues, GST and excise tax revenues.

${ }^{20}$ Commission on the Reform of Ontario's Public Services. Public Services for Ontarians: A Path to Sustainability and Excellence (Toronto: Queen's Printer for Ontario, 2012), 536, Recommendation 20-3.

21 Paul Boothe, "Introduction and Summary." in A Fine Canadian Compromise: Perspectives on the Report of the Expert Panel on Equalization and Territorial Funding Financing, ed. Paul Boothe and Francois Vaillancourt, 1-11. (Edmonton: Institute of Public Economics, University of Alberta; Montreal: CIRANO (Centre interuniversitaire de recherche en analyse des organisations)), 2007), p. 8. Expert Panel on Equalization and Territorial Formula Financing. Achieving a National Purpose: Putting Equalization Back on Track. Ottawa: Department of Finance Canada, 2006. 
Recent commentaries on reform, as the following quotations indicate, recognize the problems created by the mismatch between the main sources of federal tax revenues and the equalization entitlements created by provincial resource revenues:

As currently designed, equalization cannot undo imbalances between have and have-not provinces. It is becoming increasingly difficult for the federal government to finance full equalization commitments with only limited access to the main source of imbalances. ${ }^{22}$

A key reason why energy royalties pose such a challenge for the equalization program is that the federal government cannot constitutionally access provincial energy royalties/rents. Hence, any equalization payments driven by these energy royalties/rents must come out of the federal government's consolidated revenue fund which, in turn, means that the provinces' shares of this funding are not far off their population shares..$^{23}$

Reform options must acknowledge that the federal government collects almost no resource royalties and that the funds available to the federal government for redistribution come disproportionately from the Ontario corporate, personal, and consumption tax bases. ${ }^{24}$

The problem arising from this mismatch was first pointed out by Tom Courchene during the first oil price boom in the 1970s. Since that time, it has played an important role in shaping the program, including the adoption of the five 'representative' province standard in 1982 and, more recently, the cap on total equalization entitlements in 2009. As is widely acknowledged, the mismatch raises equity and efficiency issues that constrain or shape the equalization program. In this section, we try to advance the discussion of this issue by analyzing (albeit in a limited form) the trade-off between efficiency and entitlement.

When the federal government raises taxes to pay for equalization entitlements arising from resource rents, the higher tax rates erode incentives to work, save and invest in all of the provinces. Appendix 1 contains a description of how the efficiency loss from the federal financing of the equalization program can be calculated using the MCF concept and how this loss varies as the resource revenue inclusion rate varies. Here we will only try to provide an intuitive explanation. When resource revenues in Alberta or any non-recipient province increase, the equalization entitlements of the recipient provinces increase. (We are again assuming that there is no ceiling on total equalization payments. The issue of the ceiling will be dealt with in the next section of this paper.) We assume that the federal government increases personal income tax rates in order to finance the increase in equalization payments.

22 Robin Boadway, Serge Coulombe, and Jean-Francois Tremblay, "Canadian Policy Prescriptions for Dutch Disease," IRPP Insight 3 (Montreal: Institute for Research on Public Policy, 2013), 18.

23 Thomas Courchene, Surplus Recycling and the Canadian Federation: Addressing Horizontal and Vertical Fiscal Imbalances. Mowat Centre Fiscal Transfer Series 6, (Toronto: Mowat Centre and School of Governance and Public Policy, University of Toronto, July 2013), 11.

24 Matthew Mendelsohn, Back to Basics: The Future of the Fiscal Arrangements. Mowat Centre Fiscal Transfers Series 5, (Toronto: Mowat Centre, School of Public Policy and Governance, University of Toronto, 2012), 1. 
The increase in federal tax rates applies to incomes earned in all provinces and creates additional disincentive effects to work, save and invest. These disincentive effects also affect provincial income tax revenues because the federal and provincial personal income tax bases overlap. Thus, the cost of a federal personal income tax rate increase is not only the additional federal tax revenue and the loss caused by the induced reallocation of resources, it also includes the reduction in provincial tax revenues valued according to the provincial governments' MCFs.

Using Dahlby and Ferede's econometric estimates of the responsiveness of the personal income tax bases, the MCFs for the federal and provincial governments from a personal income tax rate increase based on 2011 rates are shown in Table $2 .{ }^{25}$ The MCFs for the recipient province are generally lower than for the non-recipient provinces because the equalization system compensates them when their tax base declines from an increase in their income tax rate. ${ }^{26}$

The columns in Table 2 show the gain to each recipient province from its equalization entitlement, where the entitlement is valued at the province's marginal cost of public funds. If resource revenues were not included in the equalization formula, Ontario would not be a recipient of equalization payments. The total gain to the recipient provinces would be $\$ 16.41$ billion. The cost, however, of financing equalization grants from a country-wide federal personal income tax increase would be $\$ 16.67$ billion, which would result in an annual net welfare or efficiency loss of $\$ 259.04$ million or $\$ 7.55$ per capita.

\section{TABLE 2 CALCULATING THE EFFICIENCY-FISCAL EQUITY TRADE-OFF}

\begin{tabular}{|c|c|c|c|c|c|}
\hline & \multicolumn{5}{|c|}{$\begin{array}{l}\text { Net Gain or Loss from the Equalization Transfers Valued at the } \\
\text { Provincial and Federal MCFs in Millions of Dollars }\end{array}$} \\
\hline & \multicolumn{5}{|c|}{ Resource Revenue Inclusion Rate, $Y$} \\
\hline & MCF & 0.00 & 0.25 & 0.50 & 1.00 \\
\hline Nfld. & 1.690 & 0.00 & 0.00 & 0.00 & 0.00 \\
\hline P.E.I. & 1.045 & 303.33 & 329.62 & 355.91 & 408.50 \\
\hline N.S. & 1.151 & $1,590.81$ & $1,730.88$ & $1,870.94$ & $2,151.07$ \\
\hline N.B. & 0.928 & $1,270.58$ & $1,359.99$ & $1,449.41$ & $1,628.24$ \\
\hline Que. & 1.426 & $11,673.45$ & $12,511.77$ & $13,350.09$ & $15,026.72$ \\
\hline Ont. & 1.297 & 0.00 & 994.00 & $3,900.46$ & $9,713.38$ \\
\hline Man. & 1.024 & $1,575.41$ & $1,740.86$ & $1,906.31$ & $2,237.22$ \\
\hline Sask. & 1.860 & 0.00 & 0.00 & 0.00 & 0.00 \\
\hline Alta. & 1.440 & 0.00 & 0.00 & 0.00 & 0.00 \\
\hline B.C. & 1.820 & 0.00 & 0.00 & 0.00 & 0.00 \\
\hline Federal Financing & 1.306 & $-16,672.63$ & $-18,969.93$ & $-23,192.97$ & $-31,639.05$ \\
\hline Net Gain (millions of \$) & -259.04 & -302.81 & -359.85 & -473.92 & \\
\hline Net Gain ( $\$$ per capita) & & -7.55 & -8.82 & -10.48 & -13.80 \\
\hline $\begin{array}{l}\text { Coefficient of Variation in } \\
\text { Fiscal Capacity (\%) }\end{array}$ & & 27.49 & 25.85 & 25.17 & 23.82 \\
\hline
\end{tabular}

25 Dahlby and Ferede, "The Effects of Tax Rate Changes," 844-883.

${ }^{26}$ For the incentive effects of the equalization grant system, see Michael Smart, "Taxation and Deadweight Loss in a System of Intergovernmental Transfers," Canadian Journal of Economics 31, no. 1 (1998): 189-206. For the computations that underlie these figures, see Dahlby and Ferede, "The Effects of Tax Rate Changes," 844-883. 
In the absence of equalization entitlements from resource revenues, there would be a large variation in fiscal capacities across provinces. As a summary measure of the degree of fiscal inequity, we report the coefficient of variation in provincial fiscal capacities. In the absence of equalization entitlements due to resource revenues, the coefficient of variation in fiscal capacity would be 27.49 per cent. With a 25 per cent resource revenue inclusion rate, Ontario would be an equalization recipient and the coefficient of variation in fiscal capacity would decrease to 25.85 per cent. The increase in federal taxes to pay for the increase in equalization would increase the cost of the program valued at the federal MCF of 1.306 to $\$ 18.97$ billion, and the equalization program would result in a net welfare loss of $\$ 302.81$ million or $\$ 8.82$ per capita. The last two columns show the net welfare losses and the coefficients of variation with inclusion rates of 0.50 and 1.00 .

These calculations illustrate the general proposition that there is an efficiency-equity trade-off with the equalization program, and that while increasing the resource revenue inclusion rate reduces the degree of fiscal inequality, the higher federal taxes that are required to finance the enriched transfers raise the aggregate welfare loss. This trade-off is illustrated in Figure 12, which plots the per capita welfare loss against the coefficient of variation in the fiscal capacities of the provinces. The computations also indicate that there is a cost associated with increasing the resource inclusion rate to reduce fiscal inequality. The marginal cost of reducing fiscal inequality by one percentage point is $\$ 0.78$ per capita in going from zero to a 25 per cent inclusion rate. This amount increases to $\$ 2.42$ in going from 0.25 to 0.50 and higher still $\$ 2.47$ - in going from 0.50 to 1.00 .

FIGURE 12 THE EFFICIENCY-FISCAL EQUITY TRADE-OFF WITH VARIATIONS IN THE RESOURCE REVENUE INCLUSION RATE

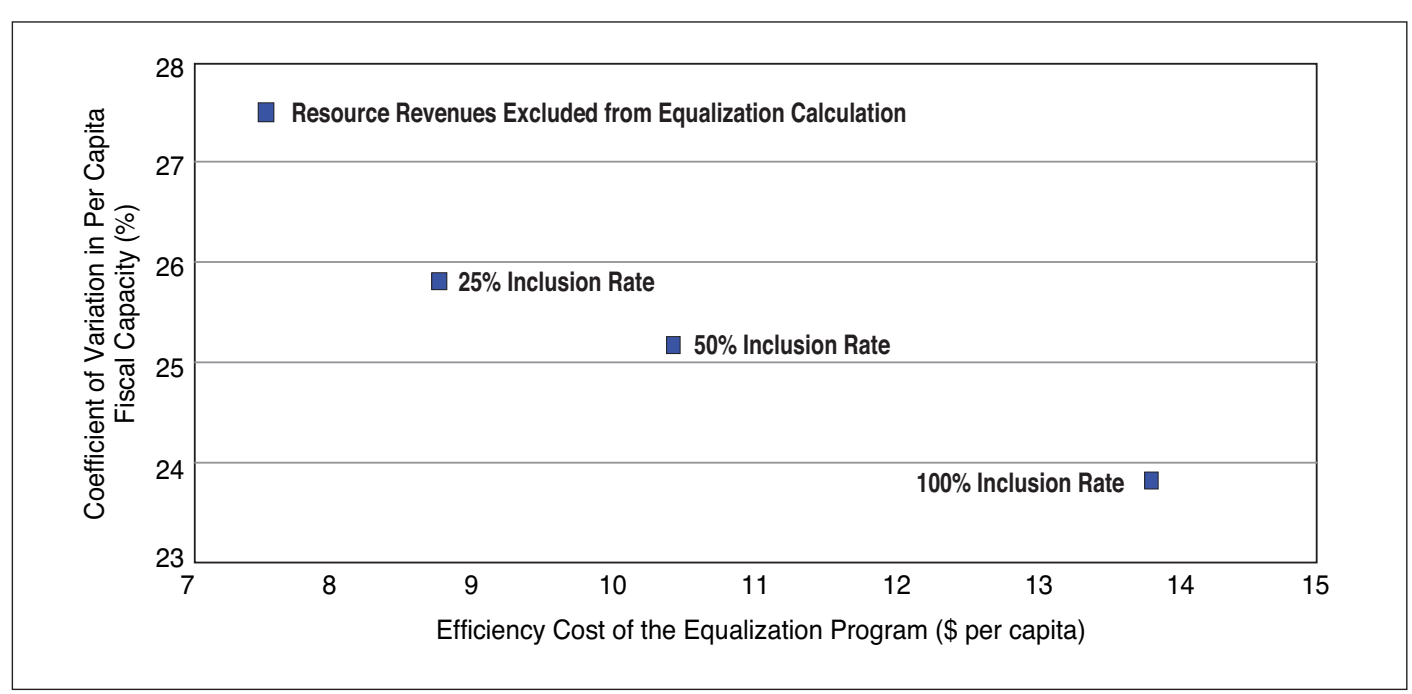

In the words of the 18th century philosopher David Hume "the distinction of vice and virtue is not founded merely on the relations of objects, nor is perceiv'd by reason. ${ }^{27}$ In the more prosaic words of a 21st century economist, the existence of an efficiency loss does not invalidate the rationale for an equalization program. Many may feel that $\$ 474$ million, or

27 David Hume, A Treatise of Human Nature, Book III: Of Morals. First published in 1738. http://www.webpages.uidaho.edu/jcanders/Ethics/david_humerp.htm 
$\$ 13.80$ per capita, is a reasonable price to pay for the full inclusion of resource revenues in the equalization formula and the reduction (but not elimination) in the variation of fiscal capacities among the provinces. What the calculations in Table 2 do not take into account, however, is the adverse effect the inclusion rate has on the provinces' willingness to develop their resources and collect revenues through royalties and pricing schemes. It is assumed that the level of resource revenue is independent of the inclusion rate and the total welfare loss from increasing the inclusion rate could be substantially greater if these incentive effects were taken into account.

Including the hydro rents that residents of Quebec and Manitoba receive because of the "underpricing" of electricity by their respective provincial utilities as resource revenue for the purposes of equalization entitlements is another frequently suggested reform. As has been pointed out by Mendelsohn, the current reduction in electricity prices in North America means that this issue could be addressed without greatly affecting the equalization entitlement of the two provinces. ${ }^{28}$ The fact that Quebec would like the anomalous treatment of Hydro Quebec and Ontario's Hydro One addressed further opens the door to reform.

Finally, let us deal with an argument that is made from time to time that resource revenues should be excluded from the equalization formula because the sale of a non-renewable resource is simply the transformation of an asset in the ground into a financial asset and, therefore, does not constitute a true source of income. Asserting that the transformation of a physical asset into a financial asset does not generate income is inconsistent with standard economic measures of income. ${ }^{29}$ For example, if one sells a one oz. gold bar for $\$ 1,250$ and buys a bond with the proceeds, he or she has transformed a physical asset into a financial asset. The Canada Revenue Agency, however, will want to know how much he or she paid for the gold bar in order to determine the capital gain that was made. Say the gold bar been purchased for $\$ 250$, the capital gain would be $\$ 1000$, on which he or she would then be obligated to pay tax on half.

According to the Hague-Simons definition, income equals consumption plus the change in net worth. If we record income from capital gains on a realization basis, then income is generated at the time of the sale of a physical asset if the cost of acquiring the asset is less than the sale price. On this basis, when a provincial government receives revenues from royalties or bonus bids, it is selling a physical asset and receiving income if the proceeds exceed the amount that the province spent to generate the revenue. From this point of view, the non-renewable resource revenue (minus the public expenditures that have been made to develop the resource) should be included in the province's fiscal capacity as it can be used to fund current operating or capital expenditures, lower taxes or reduce debt.

If we recorded capital gains as they accrue due to changes in the prices of the underlying assets as opposed to on a realization basis, then we would record as provincial income any increase or reduction in the value of the oil and gas reserves due to price changes. Of course, this would not be practical because of the huge measurement problems involved in valuing the changes in the value of oil and gas reserves. Thus the argument for partial inclusion of resource revenues is not based on the notion that "it is not a true source of income," but rather is based on efficiency arguments stemming from the federal financing of equalization payments from general taxation and from the disincentive effects for resource development and revenue generation.

\footnotetext{
28 Mendelsohn, Back to Basics.

29 See Kenneth Boessenkool, Ten Reasons to Remove Non-Renewable Resources from Equalization (Halifax: Atlantic Institute for Market Studies, 2002), 5; Robert Murphy and Brian Lee Crowley, Equalization Reform: Promoting Equity and Wise Stewardship (Ottawa: MacDonald-Laurier Institute, 2013), fn 11.
} 


\section{Removal of the Ceiling on Total Equalization Payments}

Currently, there is a ceiling on total federal expenditure on equalization that increases with the rate of nominal GDP growth. The imposition of the ceiling on equalization payments by the federal government in 2009 has been widely criticized. According to Mendelsohn, Ontario has lost $\$ 1.1$ billion in equalization payments in 2012-13, or 55 per cent of the total reduction in equalization payments, from the imposition of the ceiling. ${ }^{30}$ The Quebec government estimates the reduction in equalization transfers in 2012-13 at \$3 billion, arguing that, without the ceiling, equalization payments in 2012-13 would have been close to the historical average of 1.04 per cent of GDP instead of 0.86 per cent (see Figure 13).

Other countries also have a fixed allocation for equalization grants. In Australia, for example, equalization payments are based on total GST revenues. However, sub-national governments in other federations are less reliant on own-source tax revenues to fund their expenditures and these revenues may fluctuate due to regional economic conditions.

\section{FIGURE 13 EQUALIZATION PAYMENTS AS A PERCENTAGE OF CANADIAN NOMINAL GDP}

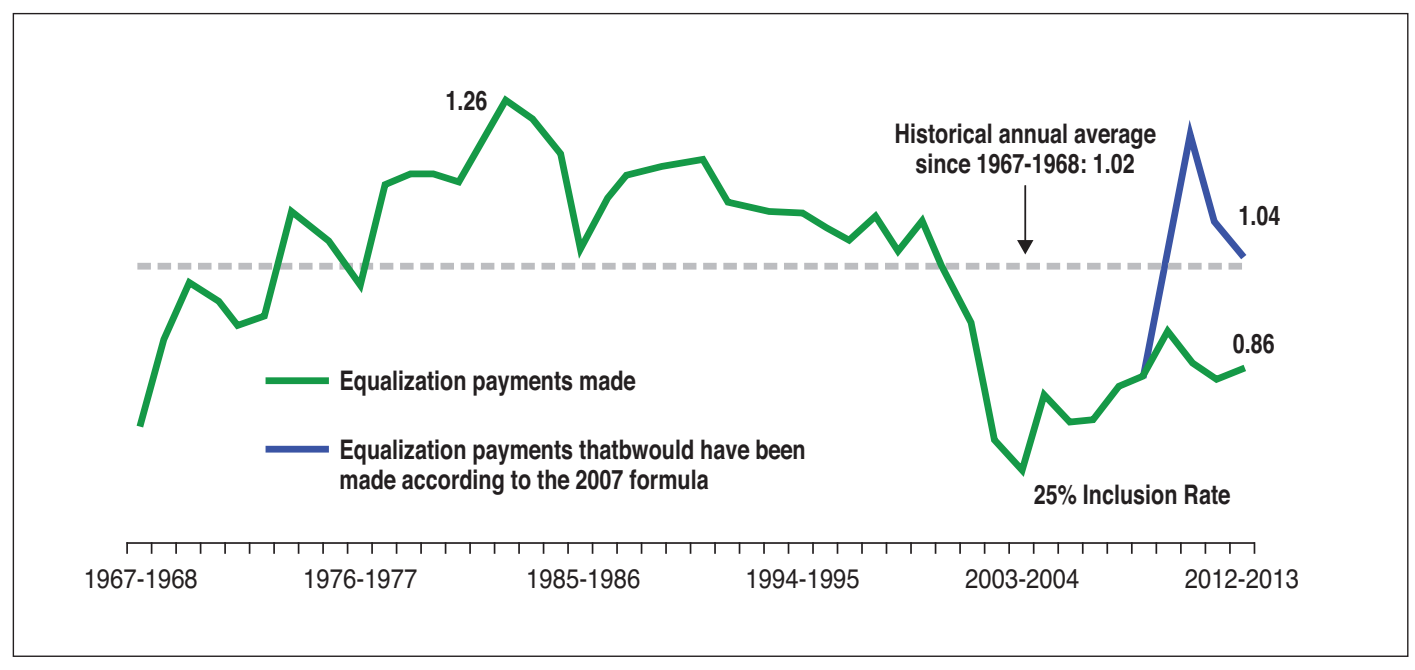

Source: Quebec (2013, Appendix E.20)

The Canadian equalization system has placed little emphasis on equalization's insurance role in spreading the fiscal effects of temporary regional shocks across all taxpayers. What is more, the imposition of the ceiling on total equalization payments has limited the extent to which shocks are shared across regions. For example, suppose there is a 10 per cent reduction in Ontario's non-resource revenue fiscal capacity and that the fiscal capacities of the other provinces remained the same. As a result of the ceiling, Ontario's equalization grants would increase while the per capita equalization grants of the other recipient provinces would be reduced. The residents of the non-recipient provinces, Saskatchewan, Alberta, British Columbia and Newfoundland and Labrador, would not see a change in their federal grants, assuming that the CHT and the CST remain fixed per capita grants. As a result of the ceiling, the fiscal impacts of province-specific shocks are limited to the taxpayers in the equalization-receiving provinces and are not shared by all taxpayers throughout the country.

${ }^{30}$ Mendelsohn, Back to Basics, 17. 
The purpose of the ceiling imposed by the federal government in 2009 was simple: to ensure rapid increases in resource revenues would not result in an attendant spike in the provinces' equalization entitlements, which, of course, Ottawa is responsible for funding. The current equalization system includes 50 per cent of a province's resource revenues in measuring its fiscal capacity. As outlined in the previous section, there are a number of reasons why a partial inclusion rate for resource revenues is appropriate, including the difficulties in measuring all resource rents accurately in assessing a province's fiscal capacities (e.g., the aforementioned issue of hydro rents in Manitoba and Quebec). Arguably, the most important reason, however, is that the bulk of resource revenues accrue to the provinces, not the federal government, and therefore, the federal tax base does not increase dollar for dollar with resource revenues.

Higher federal personal, corporate and sales tax rates to fund higher equalization payments would distort economic activity and reduce investment and growth across the country.

According to Feehan, 25 per cent has historically been considered the appropriate inclusion rate for resource revenues. From many perspectives, the 50 per cent inclusion rate recommended in the Expert Panel Report was too high, and its adoption led to the imposition of the ceiling on total equalization payments when resource revenues escalated. With a 25 per cent inclusion rate for resource revenues, the total equalization payment would have been $\$ 15.5$ billion in 2012-2013, almost the same total amount as with the current system with a 50 per cent inclusion rate and a ceiling on the growth of equalization payments. With the adoption of a 25 per cent inclusion rate for resource revenues and the removal of the ceiling on equalization payments, there would be gains and losses among the recipient provincial governments. However, the removal of the ceiling on total equalization payments would eliminate the zero-sum game aspect of the current program, which means that only the recipient provinces bear the burden of a negative fiscal shock to one of the recipient provinces.

\section{Exempting Resource Revenues Deposited in a Provincial Sovereign Wealth Fund}

Related to the aforementioned asset transformation argument is the view that resource revenues that are deposited in a provincial sovereign wealth fund (SWF) should not be included in the measures of fiscal capacity; only withdrawals from such funds should be used to calculate equalization entitlements. ${ }^{3 l}$ While there are some merits to this proposal, there are also a number of shortcomings, including the fact it would not reduce the total equalization payment in present value terms, would be complex and contentious to administer and would not alter the decision of provinces concerning whether or not to save a greater proportion of their resource revenues. Each of these points is discussed below.

First, to see that the quantum of equalization would not be affected by this proposal, let $R$ be the non-renewable resource revenues received in a given year by a province. If these revenues are spent in the current year, they would be considered fiscal capacity and included in the equalization formula (or perhaps, as under the current arrangement, only 50 per cent of them).

\footnotetext{
31 See Boadway, Coulombe, and Tremblay, "Canadian Policy Prescriptions for Dutch Disease"; Courchene, Surplus Recycling and the Canadian Federation; and Murphy and Crowley, Equalization Reform: Promoting Equity and Wise Stewardship.
} 
If they were put in a SWF by the provincial government, they would generate an annual income flow of $i R$ where $i$ is the rate of return earned by the fund. If the province uses this interest income from the fund to finance public expenditures, its fiscal capacity for equalization purposes would be $i R$. But this would generate a perpetual flow of fiscal capacity that would have a present value of $(i R) / i=R$. In other words, assuming a stable equalization system, the impact on the present value of the recipient provinces' equalization entitlements would be the same whether we count the resource revenues when they are received or the flow of interest income if it is saved in a fund. Consequently, the long-run fiscal impacts on the federal government or the recipient provinces would not be affected by the proposed treatment of resource revenues deposited in SWFs.

Of course, if resource revenues placed in SWFs were not included in measures of current fiscal capacity, there would be differences in the timing of the equalization payments and there would be advantages from a public policy perspective in smoothing these equalization payments. However, there would be practical difficulties with the proposal. Resource revenues that are used to pay down a provincial government's debt should be treated in the same way as those deposited in a SWF, but it would be very difficult to record, for equalization purposes, the increase in a province's current fiscal capacity because it used resource revenues 20 years before to pay down its debt. Also, a provincial government might put its resource revenues in a SWF fund, reducing its reported fiscal capacity in the current year, and then run a deficit equal to the amount of the resource revenue it received that year. Effectively, it would be using its current resource revenue as fiscal capacity, but then excluding it from the calculation of its entitlement for equalization payments. The federal government and the other provinces would have to scrutinize the changes in the net financial assets of the provinces in order to prevent such gaming of the system, a move that would be intrusive and highly contentious.

Finally, the way in which resource revenues are recorded for the equalization program provides little incentive for a provincial government, such as Alberta, to save its resource revenues. Albertans pay about 15 per cent of federal taxes. A change in federal equalization payments provides little incentive for the Alberta government to save more of the province's resource revenues. Indeed, the provincial government's savings decisions and the treatment of resource revenues in the calculation of equalization entitlements are two separate decisions made by two separate levels of government.

\section{Equalization of CHT and CST}

In view of the large disparities in measured fiscal capacities even with the equalization transfers, and the fact that the CST is an equal per capita grant and the CHT soon will be, Boadway et al., Mendelsohn and Courchene have argued that the CST and the CHT should be reduced for those provinces with higher fiscal capacities. ${ }^{32}$ As an example of how the clawback of the CHT and the CST might operate, Courchene has suggested that:

if a province has a per capita all-in fiscal capacity above a certain threshold, say $115 \%$, of the per capita national average of all-in fiscal capacity, then for each dollar per capita of a province's revenues above this threshold,

32 Boadway, Coulombe, and Tremblay, "Canadian Policy Prescriptions for Dutch Disease”; Mendelsohn, Back to Basics; and Courchene, Surplus Recycling and the Canadian Federation. 
Ottawa would reduce its CHT/CST transfer to this province by, say, 25 cents per capita. Given that the current value of the CHT/CST is roughly $\$ 1,200$ per capita..., if a province has an all-in fiscal capacity of $\$ 4,800$ or more per capita above the $115 \%$ per capita threshold, then its CHT/CST will fall to zero. The resulting CHT/CST clawbacks would then be redistributed to those provinces with per capita revenues below the threshold. ${ }^{33}$

Figure 14 shows the claw-back of the CHT and the CST transfers, renamed the Courchene Transfer, would have affected the fiscal capacities of the provinces in 2011-12.

\section{FIGURE 14 TOTAL REVENUE CAPACITIES OF THE PROVINCES WITH THE COURCHENE TRANSFER IN 2011-12}

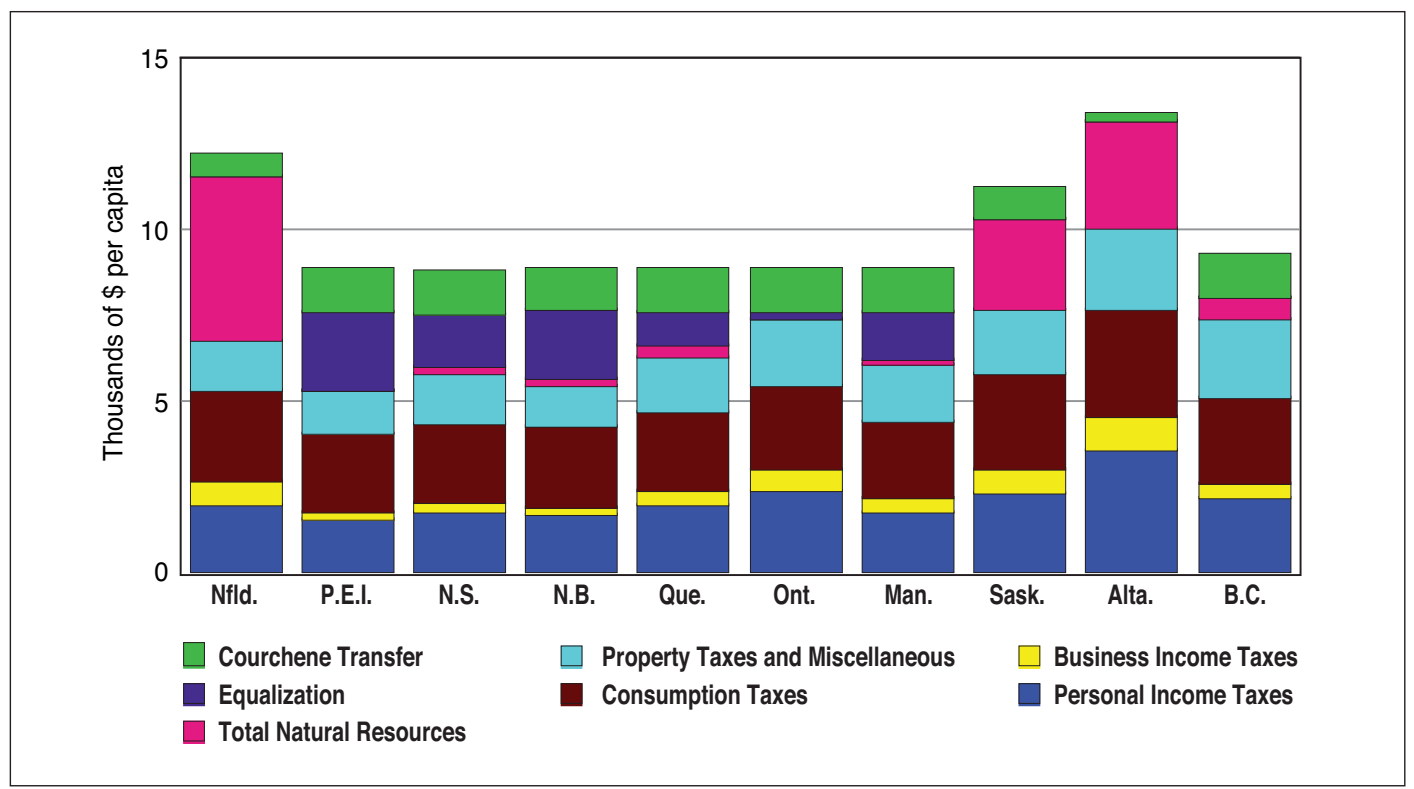

Alberta would only have been eligible for $\$ 244$ per capita compared to the average of $\$ 1,117$, and the six recipient provinces and British Columbia would have received $\$ 1,245$. With this clawback of the CHT and the CST in 2011-12, the variation in the revenue capacities of the provinces would have been reduced, with the coefficient of variation falling from 20.6 per cent to 17.2 per cent.

It is important to consider the incentive effects of clawing back transfers as the fiscal capacity or the revenues of a province improve. As they are the only provinces with all-in revenue capacities that are 15 per cent above the average, only Saskatchewan, Alberta, and Newfoundland and Labrador would have their incentives to raise taxes or increase resource revenues affected with the claw-back mechanism proposed by Courchene. These provinces would have an incentive to reduce (or at least not increase) their royalties on natural resources or make their regulatory approval of resource projects more restrictive because they would lose \$25 in CHT and CST revenues for every additional $\$ 100$ of resource revenue they received. While this claw-back rate is less than that one the recipient provinces encounter under the 50 per cent inclusion rate, it could have a larger effect on investments and revenues for the simple fact that Saskatchewan, Alberta, and Newfoundland and Labrador have greater potential resource revenues.

33 Courchene, Surplus Recycling and the Canadian Federation, 16. 
The claw-back of the CHT and the CST would also affect these provinces' incentives to raise tax rates on the other tax bases. As in the case of the recipient provinces, the claw-back would reduce a province's perceived marginal cost of public funds from raising its personal income, corporate and sales taxes because the declines in these tax bases resulting from a rate increase would be offset by higher CHT and CST grants. (Of course the increase in the CHT and the CST grants to these provinces would come at the expense of the other seven provinces.) For example, based on the 2011 tax rates, the claw-back would reduce the marginal cost of public funds for a personal income tax rate increase for Saskatchewan from 1.86 to 1.49. There would be an incentive, therefore, for Saskatchewan, Alberta, and Newfoundland and Labrador to raise their personal, corporate and consumption tax rates while reducing their resource revenues because 25 per cent of the revenue changes would come at the expense of the other provinces. This is an unintended consequence of a claw-back of the CHT and the CST, and it should be borne in mind, especially in view of the rather modest impact that a 25 per cent claw-back would have on the overall disparity in the revenue capacities of the provincial governments.

However, the main problem with proposals to claw-back the CHT and the CST from provinces with revenue capacities above some threshold is that it confuses the rationales for the equalization program and the CHT and the CST. While the purpose of the equalization transfer is to address horizontal fiscal imbalances among the provinces, the CHT and the CST are meant to address the vertical fiscal imbalance between the federal and provincial governments. As noted earlier in this paper, vertical fiscal imbalances arise in a federation because tax bases of the provincial governments are generally more tax sensitive than the federal tax bases. That is to say, tax bases are generally more mobile across provincial boundaries than across international boundaries. What is more, the provincial governments are constitutionally responsible for the "big ticket items" in a modern state (i.e., health, education and social welfare).

Alberta's fiscal capacity with respect to the personal, business and consumption tax bases would appear to be greater than that of the federal government, which could be proxied by the 10-province average that is used to compute equalization payments. The province also levies property taxes and receives resource revenues. Like those of the other provinces, however, Alberta's tax bases are much more tax sensitive than the equivalent federal tax bases. Dahlby and Ferede argue that the long-run semi-elasticity of the corporate income tax base is - 12.034 for a provincial CIT rate increase, but only -1.881 for a federal CIT rate increase.$^{34}$ For a personal income tax rate increase, the long-run semi-elasticity of the tax base is -3.073 for a provincial PIT rate increase, but only -0.495 for a federal PIT rate increase. ${ }^{35}$ These differences in the tax sensitivities of the PIT and CIT bases at the federal and provincial levels are reflected in Alberta having a higher MCF for these taxes than the federal government as shown by the computation in Table 2. Because tax bases at the provincial level are more tax sensitive than at the federal level, Alberta and the other provinces need block transfers to reduce the imbalance in their fiscal capacity with the federal government.

In designing a fiscal transfer system, the political impulse "to equalize everything" should be avoided. Rather, we should design the fiscal transfer system so that it addresses the two separate fiscal issues - horizontal imbalances and vertical imbalances. Two separate programs, therefore, are needed to accomplish these goals: equalization transfers to address

\footnotetext{
34 Dahlby and Ferede, "The Effects of Tax Rate Changes," 844-883.

35 A semi-elasticity indicates the percentage change in the tax base from a one percentage point increase in the tax rate.
} 
horizontal fiscal imbalances among the provinces and block transfers to address vertical fiscal imbalances between the provinces and Ottawa. In other words, we should fix the equalization program rather than bend the other block transfer programs out of shape.

Given the importance of the CHT and the CST in the fiscal transfer system, the design of the two merits attention. Equal per capita lump-sum transfers are consistent with the theory of intergovernmental transfers given that the equalization program addresses horizontal fiscal imbalances (recognizing, of course, that the equalization program will not fully equalize the fiscal capacities, as conventionally measured, of the provinces because of the financing and incentive constraints discussed in the Frameworks for Evaluating Equalization Transfers section of this report). Furthermore, the CHT and the CST should be combined into a single block transfer, perhaps re-labelled the "Canada Transfer" so that these transfers are no longer linked to the provision of health care, post-secondary education or social assistance. Given that their primary purpose is to address the vertical fiscal imbalances between the federal and provincial governments' revenue raising capacity, (something that affects all areas of provincial spending, not just health education and social services), the CHT should not be viewed simply as a "health care" grant and the CST as a "post-secondary education" grant. Linking these transfers to health care, post-secondary education and social assistance has obscured in the public's mind the provinces' responsibility for these programs, and thus, has reduced accountability. If we are to address the serious problem of rising health care costs, which have been highlighted in the Parliamentary Budget Office's projections, clear lines of responsibility are necessary.

In this, Prime Minister Harper's comments are correct: it is up to the provinces to solve the health care funding problem. By linking future increases in the block grants to the growth rate of the economy, the federal government can overcome the soft-budget constraint that seems to have prevented the provinces from finding innovative ways to address the growth of health care costs (e.g., using private clinics to provide basic health care services, as Saskatchewan is now trying, or making use of the health care system a taxable benefit with appropriate coinsurance rates to prevent excessive hardship in the event of catastrophic payments). Determining the quantum of funding so that the block transfers adequately address the vertical fiscal imbalances between the federal and provincial governments will be an ongoing challenge. It should not, however, be overshadowed by the task of addressing the horizontal fiscal imbalances through the equalization program.

\section{Incorporating Costs and Needs in Equalization Formula}

Unlike the Australian equalization system, the Canadian system has never incorporated provincial variations in the costs of providing public services or variations in measures of the need for services. There are major conceptual and practical problems with introducing cost and needs components in the equalization formula. A recent study by Gusen, however, indicates that a reasonable and practical approach may be feasible. ${ }^{36}$ Both Mendelsohn and Courchene endorse the use of needs and cost factors along the lines developed by Gusen. ${ }^{37}$ In their view, Ontario is being "short changed" by the current equalization system as it ignores Ontario's higher costs of providing public services and its greater need for spending in certain areas.

\footnotetext{
36 Peter Gusen, "Expenditure Needs: Equalization's Other Half," Mowat Centre 46. (Toronto: Mowat Centre, School of Public Policy and Governance, University of Toronto, 2012).

37 Mendelsohn, Back to Basics; and Courchene, Surplus Recycling and the Canadian Federation.
} 
As Courchene's puts it "the equalization program...is too generous to those provinces that have traditionally received equalization, but provides inadequate transfers to Ontario." ${ }^{38}$ What follows is a discussion of some of the conceptual issues with incorporating cost and need factors in the equalization program, followed by an examination of the specific proposal developed by Gusen. ${ }^{39}$

Public sector wages and salaries are a key determinant of the cost of public services. Incorporating this factor directly into the equalization formula, however, would create a huge incentive problem because provinces would be able to grant more generous wage settlement to their employees, while at the same time, increasing their equalization entitlement. To avoid this, an index of the average private sector wages and salaries should be used as an index of cost. Population density and the number of remote communities are two other factors that affect the cost of providing public services in a given province. By providing the provinces with the financial means needed to service these communities, equalization arguably inhibits the transition to more economically viable population distributions. Equalization entitlements based on remoteness or density would not compel the provinces to spend the funds to address the higher costs of services. In Australia, the failure of the state governments to align their spending with their needs entitlements has been a major point of contention. Similar controversies might arise in Canada if a needs component were introduced, a move that could bring the entire equalization system into disrepute.

At the conceptual level, there are problems in defining the "need" for public services versus the level of public services that are actually "demanded." In common usage, a need is something basic and essential. Viewed in this way, a "needed" public service would be a basic level of service that is essential in a modern state. Given the current levels of taxation and intergovernmental grants, it can be argued that "needed" public services are currently provided to all, or virtually all, Canadians and therefore, there is no need to include a need component in the equalization formula.

Of course, the advocates of such a component do not define needs in this way. They think of needs as the expenditure required to fund the average level of service actually provided by the provinces. The demographic makeup of a given province will play an important role in determining how much it will cost to provide the average level of service. For example, it has been estimated that the average cost of health care services is five times as great for persons over the age of 65 compared to those under 65 , meaning that per capita health care costs will be higher in Nova Scotia, where 16 per cent of the province's the population is 65 or over, than in Alberta, where just under 11 per cent of Albertans are 65 or over. ${ }^{40}$

38 Courchene, Surplus Recycling and the Canadian Federation, 1.

39 For theoretical models of equalization grant systems that include a needs component based on cost and demographic differences among provinces, see Dahlby and Leonard Wilson, "Fiscal Capacity," 657-672; and Dahlby, "An Optimal Taxation Approach to Intergovernmental Grants."

40 Government of Quebec, Budget Plan: Budget 2013-2014 (Quebec City: Ministry of Finance and Economy, 2012), E29. 
Actual program expenditures also reflect differences in preferences or the priority assigned to public services across provinces. It is not clear why a stronger preference for a public service in one province should necessitate increased federal funding to other provinces. Suppose Ontario decides to greatly expand its spending on public housing. In many formulations of the needs component of an equalization program, this would result in higher equalization entitlements in all recipient provinces. Would the increased payments to those provinces really reflect increased need in those provinces when the spending is taking place in Ontario to solve an Ontario problem?

In selecting the needs components, it would be important to avoid creating more opportunities for provinces to adopt fiscal and regulatory policies that would increase their equalization entitlements. If, as Kryvoruchko argues, the number of unemployed is included in the needs component, a province would have an incentive to increase its minimum wage or to offer short-term employment programs that allow workers to qualify for employment insurance, thereby increasing its needs entitlement under equalization..$^{41}$ MacNevin argues that the level of provincial debt is another needs factor. ${ }^{42}$ However, basing equalization payments on the level of provincial debt would only encourage and reward irresponsible fiscal behaviour by the provinces.

While there are conceptual and practical problems with incorporating cost and needs elements in the equalization system, similar problems also exist with the measurement of fiscal capacity. In that case, the equalization system has managed to overcome (or, in some cases, overlook) those problems, resulting in a system that, while far from perfect, functions reasonably well. An important step towards incorporating the cost and needs elements in the equalization system has recently been made by Gusen who has developed a "prototype" needs based equalization system. ${ }^{43}$ Here, we will only provide a brief summary of the methodology that Gusen uses to construct the needs based prototype equalization entitlements.

The Gusen prototype reflects variations in costs, geographic factors and service requirements or "workloads." The cost factors reflect differences in average earnings, construction costs, health care costs, other inter-provincial price differences and the percentage of the population remote from metropolitan areas. The resulting price index for provincial and local government services in 2008-09 is shown in Figure 15.

${ }^{41}$ Kryvoruchko, Iryna Serhiyvna, "Redistributive Effectiveness of Three Equalization Alternatives: Representative Tax, Macro-Based and Fiscal Needs Systems. Evidence for Canada" (Working paper presented at the meeting of the Canadian Economics Association, Hamilton, Ontario, May 27-29, 2005).

42 A.S. MacNevin, The Canadian Federal-Provincial Equalization Regime: An Assessment Canadian Tax Paper No. 109 (Toronto: Canadian Tax Foundation, 2004).

43 Peter Gusen, “Expenditure Needs: Equalization's Other Half," Mowat Centre 46. (Toronto: Mowat Centre, School of Public Policy and Governance, University of Toronto, 2012); and Peter Gusen, “Expenditure Needs: Equalization's Other Half" (Technical Background Paper, Mowat Centre, School of Public Policy and Governance, University of Toronto, 2012). 
FIGURE 15 A PRICE INDEX FOR PROVINCIAL-LOCAL EXPENDITURES IN 2008-09

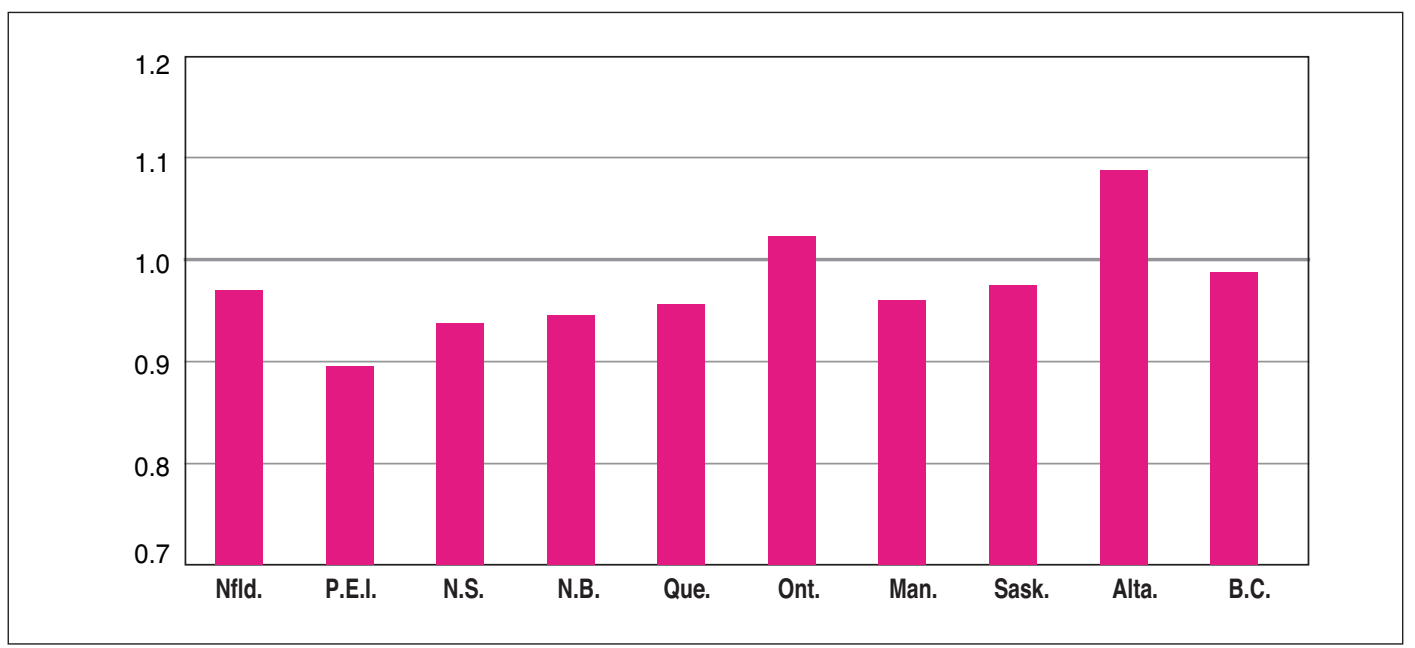

Source: Gusen (2012b, Chart 2, page 14).

The price index varies from around 1.1 in Alberta to 0.9 in P.E.I. At 1.03, Ontario's cost index is slightly above the national average, while the cost indices of all of the other recipient provinces are below the national average.

Gusen's expenditure needs components is based on demographics and expenditure levels in five areas: health care, elementary and secondary education, post-secondary education, social assistance and other social services. The per capita needs entitlements for 2008-09 are shown in Figure 16 (a positive component implies an increase in equalization entitlements, while a negative component implies a reduction).

FIGURE 16 PER CAPITA NEEDS ENTITLEMENTS IN 2008-09

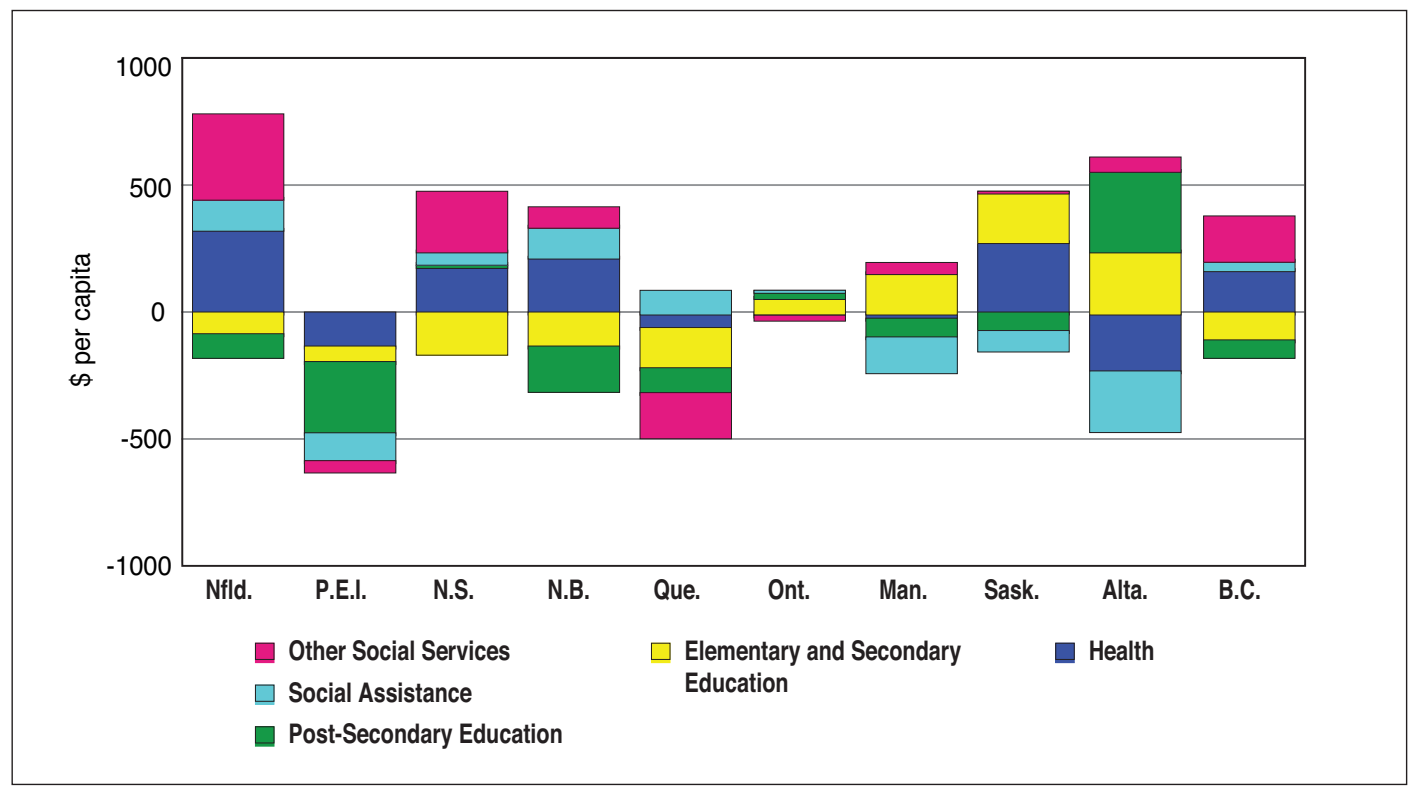


Because provinces with older populations have higher expenditure needs for health care, but lower expenditure needs for education, the health and the two education categories are offsetting in all provinces except Quebec and P.E.I. Probably the most controversial needs component in the Gusen prototype is social assistance, which is a measure of the additional income required to raise those with low incomes up to Statistics Canada's low-income thresholds. It could be argued that provinces with large low-income gaps will also have lower fiscal capacity measures and higher equalization entitlements and, therefore, it is not necessary to include the "need" for social assistance in the equalization formula. The equalization entitlements derived from social assistance would increase total equalization entitlements for the six recipient provinces by $\$ 661$ million, while reducing the entitlements for P.E.I. and Manitoba. The other needs components would reduce total equalization payments to the recipient provinces. Overall, incorporating expenditure needs would reduce the equalization entitlements of P.E.I. (-\$617), Quebec (-\$322) and New Brunswick (\$-86). On the other hand, it would increase the equalization entitlements of Ontario by (\$67), Manitoba (\$62) and Nova Scotia (\$31). The overall impact of the prototype needs based equalization entitlement in 200809 (ignoring the three-year averaging of equalization entitlements) would have been to reduce Quebec's entitlement by $\$ 3.1$ billion, P.E.I.'s by $\$ 86$ million and Manitoba's by $\$ 41$ million, while raising Ontario's entitlement by $\$ 820$ million, Nova Scotia's by $\$ 294$ million and New Brunswick's by $\$ 83$ million. The total reduction in equalization entitlements from adopting the prototype needs based equalization system would be $\$ 2$ billion in 2008-09..$^{44}$ Of course the changes in the total amount of equalization, if the needs component were adopted, would also depend on changes to other parameters of the equalization system, such as the resource revenue inclusion rate and the ceiling on total equalization payments.

Gusen's prototype demonstrates that it is feasible to construct needs entitlements with existing data collected by Statistics Canada that would broadly correct for differences in the costs and demographic characteristics across provinces. It would redistribute equalization payments across provinces, with Quebec and P.E.I. losing entitlements and Ontario gaining a relatively modest amount in per capita terms. At a minimum, Gusen's analysis should place the incorporation of needs high on the policy reform agenda.

\section{Other Fiscal Reforms}

The equalization program is sometimes referred to as the backbone of the Canadian federation. Given its central role, it is not surprising that proposals to reform the equalization system often encompass a wide range of other associated fiscal reforms. Some might argue that a large package of reforms, which extends beyond the narrow definition of the equalization program, is necessary to achieve an acceptable agreement for all regions. Here, we will briefly touch on some of the wider fiscal reforms that have been associated with changes to the equalization system.

44 Gusen, “Expenditure Needs: Equalization's Other Half” (Technical Background Paper), 37 Table 39. 
In view of the mismatch between federal funding of equalization and provincial resource revenues that give rise to equalization entitlements, Boadway et al. and Courchene propose that the federal government obtain a larger share of the economic rents generated by resource industries by reforming the federal corporate income tax. ${ }^{45}$ Specifically, they propose that Canada adopt an Allowance for Corporate Equity (ACE) base that would apply in all industries. By providing a deduction for a return on shareholders' equity as well as interest on corporate debt, the ACE system removes the bias in favour of debt financing and converts the corporate income tax into a tax on economic rents. Since much of the resource sector, especially the oil and gas industry, generates most of the economic rent, this reform would tend to shift the corporate tax burden from manufacturing and services sectors to the resource sector. They also propose other changes to the corporate income tax system that would more directly affect the resource sector, such as disallowing the deduction of provincial royalties from the federal corporate income tax base or limiting the credits for oil and gas exploration and development expenditures. It is the author's view, however, that these reforms of the corporate income tax should be evaluated on their overall merits, including their effects on corporate investment incentives and international transfer pricing and should not be solely motivated by an attempt to fix the equalization financing problem.

Boadway et al. argue that the federal industrial policies should focus on strengthening the nonresource-rich regions, with federal infrastructure grants acting as a counterbalance to "those undertaken in resource-rich provinces. ${ }^{" 46}$ Again, this emphasis on restructuring federal infrastructure programs to address horizontal fiscal imbalances would alter the primary purpose of these matching grants (i.e., to deal with the horizontal and vertical externalities that arise from provincial and local infrastructure investments). Infrastructure projects in Calgary generate additional personal, corporate and consumption tax revenues for the federal government, just as infrastructure projects in Toronto do. The federal government should provide matching grants for infrastructure projects for all provincial governments based on the extent of their vertical and horizontal (i.e., interprovincial) benefit spillovers, both direct and fiscal benefits, and not as an offset for the limitations of the equalization program. ${ }^{47}$

Linking other fiscal issues, such as Employment Insurance or a federal carbon tax, to the reform of the equalization system has been proposed by Courchene. ${ }^{48}$ But these topics have proven so contentious in the past, and are such important issues in their own right, that it would probably be a mistake to try to bundle them with reforms to the equalization system (especially if we want to see such reforms in our lifetime).

45 Boadway, Coulombe, and Tremblay, "Canadian Policy Prescriptions for Dutch Disease"; Mendelsohn, Back to Basics; and Courchene, Surplus Recycling and the Canadian Federation.

46 Boadway, Coulombe, and Tremblay, "Canadian Policy Prescriptions for Dutch Disease," 23.

47 For a discussion on the design of matching infrastructure grants to deal with horizontal and vertical spillovers, see Dahlby, “An Optimal Taxation Approach to Intergovernmental Grants."

48 Courchene, Surplus Recycling and the Canadian Federation. 


\section{RECOMMENDATIONS}

In the interest of keeping a long paper from growing even longer, we will dispense with a lengthy summary of the analysis and focus on a set of recommendations for the reform of the fiscal transfer system that flow from the above analysis. Recommendations are divided into a list of "dos" and "don'ts."

\section{Do}

- Lower the resource revenue inclusion rate to $25 \%$;

- Remove the ceiling on total equalization payments;

- Incorporate cost and needs factors along the lines of the Gusen report into the equalization program;

- Combine the CHT and the CST into a single block transfer called the Canada Transfer; and

- Make the Canada Transfer an equal per capita transfer to all provinces with a fixed schedule of increases linked to the GDP growth rate and re-examine its funding every five years.

\section{DON'T}

- Exempt resource revenues deposited in provincial sovereign wealth funds;

- Claw-back the CHT and the CST based on the fiscal capacities of the province; and

- Carry out unrelated fiscal reforms in the name of equalization.

This set of recommendations, while not addressing all of the concerns raised by the provinces and the various commentators, would address at least some of the efficiency, entitlement and ownership issues that constrain and shape any reforms to our fiscal transfer system. 


\section{APPENDIX 1}

\section{Calculating the Marginal Cost of Public Funds from Federal Financing of Equalization Payments}

We assume the tax changes are evaluated based on the following utilitarian social welfare function:

$$
S W F=\sum_{i} p_{i} V\left(t_{i}+T, g_{i}, G\right)
$$

where $p_{i}$ is the population of province $i, V($.$) is the indirect utility function of a representative$ individual, $t_{i}$ is the provincial income tax rate, $T$ is the federal income tax rate, and $g_{i}$ and $G$ are the provincial and federal public goods. Let $R_{i}=t_{i} y_{i}$ be the provincial per capita income tax revenue where $y_{i}$ is the income of the representative taxpayer in province $i$ and $R=T \cdot \bar{y}$ is the federal per capita tax revenue where $\bar{y}$ is the national average income.

Differentiating the SWF with respect to T we obtain:

$$
\frac{\partial S W F}{\partial T}=\sum_{i} p_{i} \frac{\partial V}{\partial T}+p_{i} \frac{\partial V}{\partial g_{i}} \frac{\partial g_{i}}{\partial R_{i}} \frac{\partial R_{i}}{\partial T}
$$

where the decline in provincial provision of public goods occurs because of the negative vertical externality from the federal tax rate increase.

From Roy's theorem and valuing the change in provincial at the provincial marginal cost of public funds, $M C F_{i}$, we obtain the following:

$$
\frac{\partial S W F}{\partial T}=\sum_{i}-p_{i} \lambda_{i} y_{i}\left[1-M C F_{i} t_{i} h_{i}\right]
$$

where $\eta_{i}<0$ is the semi-elasticity of $y_{i}$ with respect to $T$ and $\lambda_{i}$ is the marginal utility of income for the representative individual in province $i$. We assume that $\lambda_{i}=1$ in all provinces and define the marginal cost of federal tax rate increase as:

$$
M C F_{T}=-\frac{\frac{\partial S W F}{\partial T}}{\frac{\partial R}{\partial T}}=\frac{\sum_{i} p_{i}\left(\frac{y_{i}}{\bar{y}}\right)\left[1-M C F_{i} t_{i} \eta_{i}\right]}{1+T_{i} \eta_{F}}
$$

where $\eta_{F}<0$ is the semi-elasticity of the federal tax base with respect to a federal tax rate increase. The above expression is used to calculate the cost of federal financing of changes in the equalization grant system in Table 2 as the resource revenue inclusion rate changes. 



\section{ABOUT THE SCHOOL OF PUBLIC POLICY}

The School of Public Policy will become the flagship school of its kind in Canada by providing a practical, global and focused perspective on public policy analysis and practice in areas of energy and environmental policy, international policy and economic and social policy that is unique in Canada.

The mission of The School of Public Policy is to strengthen Canada's public service, institutions and economic performance for the betterment of our families, communities and country. We do this by:

- Building capacity in Government through the formal training of public servants in degree and non-degree programs, giving the people charged with making public policy work for Canada the hands-on expertise to represent our vital interests both here and abroad;

- Improving Public Policy Discourse outside Government through executive and strategic assessment programs, building a stronger understanding of what makes public policy work for those outside of the public sector and helps everyday Canadians make informed decisions on the politics that will shape their futures;

- Providing a Global Perspective on Public Policy Research through international collaborations, education, and community outreach programs, bringing global best practices to bear on Canadian public policy, resulting in decisions that benefit all people for the long term, not a few people for the short term.

Our research is conducted to the highest standards of scholarship and objectivity. The decision to pursue research is made by a Research Committee chaired by the Research Director and made up of Area and Program Directors. All research is subject to blind peer-review and the final decision whether or not to publish is made by an independent Director.

\section{The School of Public Policy}

University of Calgary, Downtown Campus

906 8th Avenue S.W., 5th Floor

Calgary, Alberta T2P $1 \mathrm{H} 9$

Phone: 4032107100

\section{DISTRIBUTION}

Our publications are available online at www.policyschool.ca.

\section{DISCLAIMER}

The opinions expressed in these publications are the authors' alone and therefore do not necessarily reflect the opinions of the supporters, staff, or boards of The School of Public Policy.

\section{COPYRIGHT}

Copyright (C) 2014 by The School of Public Policy.

All rights reserved. No part of this publication may be reproduced in any manner whatsoever without written permission except in the case of brief passages quoted in critical articles and reviews.

\section{DATE OF ISSUE}

September 2014

\section{MEDIA INQUIRIES AND INFORMATION}

For media inquiries, please contact Morten Paulsen at 403-453-0062.

Our web site, www.policyschool.ca, contains more information about The School's events, publications, and staff.

\section{DEVELOPMENT}

For information about contributing to The School of Public Policy, please contact Courtney Murphy by telephone at 403-210-7201 or by e-mail at cdmurphy@ucalgary.ca.

\section{ISSN}

1919-112x SPP Research Papers (Print) 1919-1138 SPP Research Papers (Online) 


\section{RECENT PUBLICATIONS BY THE SCHOOL OF PUBLIC POLICY}

WIRELESS COMPETITION IN CANADA: DAMN THE TORPEDOES! THE TRIUMPH OF POLITICS OVER ECONOMICS http://policyschool.ucalgary.ca/sites/default/files/research/church-wirelessupd2014-v6.pdf Jeffrey Church and Andrew Wilkins | August 2014

THE FUTURE OF ENERGY REGULATION AND POLICY DEVELOPMENT: A SUMMARY PAPER http://policyschool.ucalgary.ca/sites/default/files/research/energyregul5.pdf Shantel Beach, Andrew Wilkins and Jennifer Winter | August 2014

"IT'S ALL ABOUT THE MONEY": CRIME IN THE CARIBBEAN AND ITS IMPACT ON CANADA http://policyschool.ucalgary.ca/sites/default/files/research/ross-caribbeancrime.pdf Cameron Ross | July 2014

RISKY BUSINESS: THE ISSUE OF TIMING, ENTRY AND PERFORMANCE IN THE ASIA-PACIFIC LNG MARKET

http://policyschool.ucalgary.ca/sites/default/files/research/moore-Ing-onl.pdf

David Hackett, Roman Karski, Michal Moore, Leigh Noda, Mark Pilcher and Jennifer Winter | July 2014

WHO, OR WHAT, IS TO BLAME FOR THE ACCUMULATION OF DEBT IN ONTARIO AND QUEBEC (AND WHAT WILL IT TAKE TO STOP THE BLEEDING?) http://policyschool.ucalgary.ca/sites/default/files/research/kneebone-ontdebt3.pdf Margarita Wilkins and Ron Kneebone | July 2014

THE IMPACT OF FOREIGN INVESTMENT RESTRICTIONS ON THE STOCK RETURNS OF OIL SANDS COMPANIES http://policyschool.ucalgary.ca/sites/default/files/research/beaulieau-foreign-inv.pdf Eugene Beaulieu and Matthew Saunders | June 2014

FROM TRIAL TO TRIUMPH: HOW CANADA'S PAST FINANCIAL CRISES HELPED SHAPE A SUPERIOR REGULATORY SYSTEM http://policyschool.ucalgary.ca/sites/default/files/research/savage-financeevol.pdf Lawrie Savage | May 2014

THE FREE RIDE IS OVER: WHY CITIES, AND CITIZENS, MUST START PAYING FOR MUCH-NEEDED INFRASTRUCTURE http://policyschool.ucalgary.ca/sites/default/files/bazelmintz-urban-growth.pdf Philip Bazel and Jack Mintz | May 2014

ALBERTA CITIES AT THE CROSSROADS: URBAN DEVELOPMENT CHALLENGES AND OPPORTUNITIES IN HISTORICAL AND COMPARATIVE PERSPECTIVE http://policyschool.ucalgary.ca/sites/default/files/research/taylor-ab-cities-5.pdf Anna Kramer, Marcy Burchfield and Zack Taylor | May 2014

ONTARIO'S EXPERIMENT WITH PRIMARY CARE REFORM

http://policyschool.ucalgary.ca/sites/default/files/ontario-health-care-reform.pdf Gioia Buckley and Arthur Sweetman | May 2014

THE MIDDLE POWER AND THE MIDDLE KINGDOM: SECURING CANADA'S PLACE IN THE NEW CHINA-U.S. ECONOMIC AND STRATEGIC WORLD ORDER http://policyschool.ucalgary.ca/sites/default/files/dobson-china-communique.pdf Wendy Dobson | April 2014

SAFETY IN NUMBERS: EVALUATING CANADIAN RAIL SAFETY DATA

http://policyschool.ucalgary.ca/sites/default/files/research/winter-rail-safety-communique.pdf Jennifer Winter | April 2014

CHINA'S STATE-OWNED ENTERPRISES AND CANADA'S FDI POLICY

http://policyschool.ucalgary.ca/sites/default/files/research/dobson-china.pdf Wendy Dobson | March 2014 